\title{
New strategies for Alzheimer disease and cognitive impairment
}

\author{
Kenneth Maiese, ${ }^{1-5, *}$ Zhao Zhong Chong,' Jinling Hou' and Yan Chen Shang'
}

\begin{abstract}
'Division of Cellular and Molecular Cerebral Ischemia; ${ }^{2}$ Departments of Neurology and Anatomy \& Cell Biology; ${ }^{3}$ Barbara Ann Karmanos Cancer Institute; ${ }^{4}$ Center for Molecular Medicine and Genetics; Institute of Environmental Health Sciences; Wayne State University School of Medicine; Detroit, MI USA
\end{abstract}

Key words: aging, Alzheimer disease, angiogenesis, apoptosis, cognitive loss, diabetes, erythropoietin, forkhead transcription factors, immune system, ischemia, neurodegeneration, oxidative stress, vascular disease, Wnt, wingless

Approximately five million people suffer with Alzheimer disease (AD) and more than twenty-four million people are diagnosed with $A D$, pre-senile dementia, and other disorders of cognitive loss worldwide. Furthermore, the annual cost per patient with AD can approach $\$ 200,000$ with an annual population aggregate cost of $\$ 100$ billion. Yet, complete therapeutic prevention or reversal of neurovascular injury during $A D$ and cognitive loss is not achievable despite the current understanding of the cellular pathways that modulate nervous system injury during these disorders. As a result, identification of novel therapeutic targets for the treatment of neurovascular injury would be extremely beneficial to reduce or eliminate disability from diseases that lead to cognitive loss or impairment. Here we describe the capacity of intrinsic cellular mechanisms for the novel pathways of erythropoietin and forkhead transcription factors that may offer not only new strategies for disorders such as AD and cognitive loss, but also function as biomarkers for disease onset and progression.

\section{Introduction}

Alzheimer disease, cognitive loss, novel cellular pathways. For the population in the United States, the National Institute on Aging estimates that almost five million people have Alzheimer's disease (AD). Furthermore, more than twenty-four million people suffer from $\mathrm{AD}$, pre-senile dementia, and other disorders of cognitive loss worldwide. If one then includes other related degenerative disorders of the central nervous system (CNS), the scope of these illnesses approach 370 million people throughout the globe. With these disorders of cognition, the cost of physician services, hospital and nursing home care, and medications continues to rise dramatically. In addition, the medical costs parallel a progressive loss of economic productivity with rising morbidity and mortality, ultimately resulting in an annual deficit to the economy that is greater than $\$ 400$ billion. Interestingly, the most significant portion of this economic loss is composed of only a few neurodegenerative disease entities, such as ischemic disease

*Correspondence to: Kenneth Maiese; Email: kmaiese@med.wayne.edu; aa2088@wayne.edu

Submitted: 07/22/09; Revised: 08/24/09; Accepted: 09/02/09

Previously published online:

www.landesbioscience.com/journals/oximed/article/9990 and $\mathrm{AD}$. The annual cost per patient with $\mathrm{AD}$ is estimated at greater than $\$ 174,000$ with an annual population aggregate cost of $\$ 100$ billion. ${ }^{1,2}$

Despite the current understanding of the cellular pathways that modulate CNS injury during $\mathrm{AD}$ and cognitive disorders, complete therapeutic prevention or reversal of neurovascular injury during $\mathrm{AD}$ or dementia is not achievable. As a result, identification of novel therapeutic targets for the treatment of neurovascular injury would be extremely beneficial to reduce or eliminate disability from diseases that lead to cognitive loss or impairment. Current studies have begun to focus on pathways of oxidative stress that involve a variety of cellular pathways in the neurovascular systems. Here we describe the capacity of intrinsic cellular mechanisms that may offer novel therapy for disorders such as AD. Oxidative stress leads to apoptotic injury that involves early loss of cellular membrane asymmetry as well as the eventual destruction of genomic DNA. These dynamic stages of oxidative stress and apoptosis can be governed by cytokines such as erythropoietin (EPO) and transcription factors such as forkhead. Further understanding of these pathways may provide new insight for novel strategies that can treat $\mathrm{AD}$ and cognitive disorders as well as the complications associated with these disorders.

Oxidative stress and neurovascular injury. Release of reactive oxygen species (ROS) that consist of oxygen free radicals and other chemical entities can result in the development of oxidative stress in the body. Oxygen free radicals can be generated in elevated quantities during the reduction of oxygen and lead to cell injury. ROS can involve superoxide free radicals, hydrogen peroxide, singlet oxygen, nitric oxide (NO) and peroxynitrite..$^{3-5}$ Most species are produced at low levels during normal physiological conditions and are scavenged by endogenous antioxidant systems that include superoxide dismutase (SOD), glutathione peroxidase, catalase and small molecule substances such as vitamins $\mathrm{C}$ and $\mathrm{E}$. Other closely linked pathways to oxidative stress may be tempered by different vitamins, such as vitamin $\mathrm{D}_{3},{ }^{6}$ and the amide form of niacin or vitamin $\mathrm{B}_{3}$, nicotinamide. ${ }^{7-13}$

Oxidative stress leads to the destruction of multiple cell types through apoptotic pathways. ${ }^{14-16}$ Apoptotic induced oxidative stress in conjunction with processes of mitochondrial dysfunction $^{17-19}$ can contribute to a variety of disease states such as diabetes, ischemia, cognitive loss, Alzheimer's disease and trauma. ${ }^{3,20-23}$ Oxidative stress can lead to apoptosis in neurons, endothelial 
cells (ECs), cardiomyocytes and smooth muscle cells that involve separate as well as overlapping pathways. ${ }^{21,24-28}$

Apoptosis is a dynamic process that consists of both the early exposure of membrane phosphatidylserine (PS) residues and the late destruction of genomic DNA. ${ }^{29,30}$ Externalization of membrane PS residues is an early event during cell apoptosis ${ }^{31,32}$ and can become a signal for the phagocytosis of cells. ${ }^{16,33,34}$ The loss of membrane phospholipid asymmetry leads to the exposure of membrane PS residues on the cell surface and assists microglia to target cells for phagocytosis. ${ }^{13,26,35-37}$ This process occurs with the expression of the phosphatidylserine receptor (PSR) on microglia during oxidative stress. ${ }^{38,39}$ It has been shown that blockade of PSR function in microglia prevents the activation of microglia. ${ }^{36,40}$ Externalization of membrane PS residues occurs in neurons, vascular cells and inflammatory microglia in conjunction with $\mathrm{AD}$ and cognitive loss during reduced oxygen exposure, ${ }^{16,41-44} \beta$-amyloid (A $\beta$ ) exposure ${ }^{45,46}$ during AD progression, nitric oxide exposure, ${ }^{47-51}$ and during the administration of agents that induce the production of ROS, such as 6-hydroxydopamine. ${ }^{52}$ Membrane PS externalization on platelets also has been associated with clot formation in the vascular system. ${ }^{53}$

The cleavage of genomic DNA into fragments ${ }^{43,54,55}$ usually occurs after membrane PS exposure ${ }^{56}$ and is considered to be a later event during apoptotic injury. ${ }^{26,55,57,58}$ Several enzymes responsible for DNA degradation include the acidic, cation independent endonuclease (DNase II), cyclophilins, and the $97 \mathrm{kDa}$ magnesium-dependent endonuclease., ${ }^{3,59}$ Three separate endonuclease activities also have been found in neurons that include a constitutive acidic cation-independent endonuclease, a constitutive calcium/magnesium-dependent endonuclease, and an inducible magnesium dependent endonuclease. ${ }^{60,61}$

During oxidative stress, mitochondrial membrane transition pore permeability also is increased, ${ }^{12,26,62,63}$ a significant loss of mitochondrial $\mathrm{NAD}^{+}$stores occurs, and further generation of superoxide radicals leads to cell injury. ${ }^{13,64}$ Mitochondria are a significant source of superoxide radicals that are associated with oxidative stress. ${ }^{3,65}$ Blockade of the electron transfer chain at the flavin mononucleotide group of complex I or at the ubiquinone site of complex III results in the active generation of free radicals which can impair mitochondrial electron transport and enhance free radical production. ${ }^{38,59}$ Furthermore, mutations in the mitochondrial genome have been associated with the potential development of a host of disorders, such as hypertension, hypercholesterolemia and hypomagnesemia. ${ }^{66,67}$ ROS also may lead to cellular acidosis and subsequent mitochondrial failure. ${ }^{20}$ Disorders, such as hypoxia, ${ }^{68}$ diabetes ${ }^{69,70}$ and excessive free radical production ${ }^{61,71,72}$ can result in the disturbance of intracellular $\mathrm{pH}$.

\section{Erythropoietin (EPO) and its Receptor}

EPO and the EPO receptor. The EPO gene is located on chromosome 7 , exists as a single copy in a $5.4 \mathrm{~kb}$ region of the genomic DNA, and encodes a polypeptide chain containing 193 amino acids. During the production and secretion of EPO, a circulatory mature protein of 165 amino acids is produced. ${ }^{73,74}$ The principal organs of EPO production and secretion are the kidney, liver, brain and uterus. EPO production and secretion occurs foremost in the kidney. ${ }^{75}$

Interestingly, increased levels of EPO in the fetal plasma and amniotic fluid during gestation may function as a biomarker of intrauertine hypoxia. ${ }^{76}$ For biological systems, a "biomarker" can consist of any entity that occurs in the body and that can be measured to predict the diagnosis, onset or progression of a disease process. ${ }^{77}$ Novel pathways that involve the cytokine and growth factor EPO may indicate that the increased presence of this agent during periods of oxidative stress may lead to cellular mechanisms to protect against ROS. ${ }^{74,78,79}$ Recent studies have demonstrated that EPO is not only required for erythropoiesis, but also functions in other organs and tissues, such as the brain, heart and vascular system that can be relevant for the treatment of $\mathrm{AD}^{40,80-84}$ (Fig. 1). EPO production is believed to occur throughout the body $y^{5,74,85}$ and can be detected in the breath of healthy individuals. ${ }^{86}$ In addition, it has been suggested that EPO may provide developmental cognitive support. In experimental animal models, EPO may reduce apoptotic pathways during periods of hyperoxia in the developing brain. ${ }^{87,88}$ Furthermore, clinical disorders may have periods of hyperoxia followed by cerebral hypoperfusion and hypoxia that can lead to cerebral injury with associated oxidative stress. ${ }^{89}$ In these circumstances, EPO also may be protective since it can promote neurite outgrow th ${ }^{90}$ and also may regulate hemoglobin levels that have recently been associated with cognitive decline. ${ }^{91}$ In other work, elevated EPO concentrations during infant maturation have been correlated with increased Mental Development Index scores ${ }^{92}$ and EPO may prevent toxic effects of agents used to control cognitive function such as haloperidol. ${ }^{3}$

In addition, knowledge that EPO and its receptor are present in the neurovascular systems has generated great enthusiasm for the potential clinical applications of EPO for AD and related cardiac insufficiency ${ }^{94,95}$ and cardiac transplantation. ${ }^{96,97}$ In the nervous system, primary sites of EPO production and secretion are in the hippocampus, internal capsule, cortex, midbrain, cerebral endothelial cells (ECs) and astrocytes. ${ }^{73,74,98,99}$ Further work has revealed several other organs as secretory tissues for EPO that include peripheral ECs, ${ }^{100}$ myoblasts, ${ }^{101}$ insulinproducing cells ${ }^{102}$ and cardiac tissue. ${ }^{74,75}$ The EPOR also is expressed in primary cerebral $\mathrm{ECs}^{63,103}$ as well as in human umbilical veins, bovine adrenal capillaries and rat brain capillaries. ${ }^{100,104}$

Despite the fact that EPO is a critical modulator of erythropoiesis, the presence of a diminished oxygen tension is required rather than a low concentration of red blood cells. ${ }^{5,78,79,105}$ Gene transcription of EPO is mediated by the transcription enhancer located in the 3'-flanking region of the EPO gene that specifically binds to hypoxia-inducible factor 1 (HIF-1). ${ }^{73,74}$ Yet, hypoxia is not the only condition that can alter the expression of EPO and the EPOR. A variety of cellular disturbances may lead to either increased or decreased EPO expression through the control of HIF, such as hypoglycemia, cadmium exposure, raised intracellular calcium, or intense neuronal depolarizations generated by mitochondrial ROS. ${ }^{99,106,107}$ Anemic stress, insulin release and several cytokines, including insulin-like growth factor, tumor 


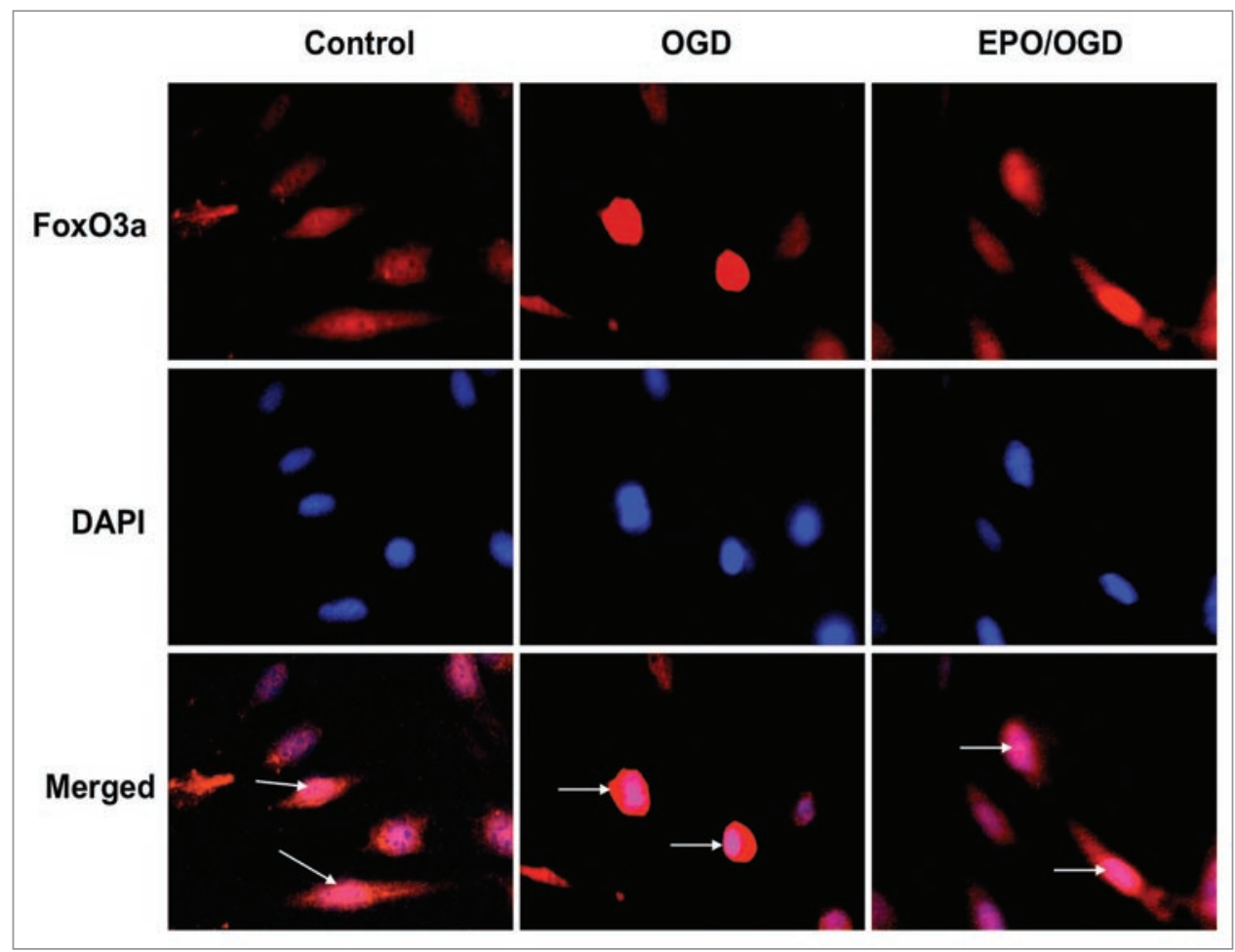

Figure I. Erythropoietin (EPO) regulates the intracellular trafficking of the forkhead transcription factor FoxO3a in endothelial cells (ECs) during oxygen glucose deprivation (OGD). EPO (I0 ng/ml) was administered to ECs I hour prior to exposure of OGD for an 8 hour period. Immunofluorescent staining for FoxO3a at 6 hours following OGD was performed with primary rabbit anti-FoxO3a antibody followed by Texas red conjugated antirabbit secondary antibody. Nuclei of ECs were counterstained with DAPI. Control cells were untreated and not exposed to OGD. In control cells, FoxO3a remains primarily in the cytoplasm of cells with the nuclei visible in merged images and indicated by the white arrows. In contrast, OGD activates FoxO3a to translocate to the nucleus demonstrating FoxO3a in the cytoplasm and nuclei of these cells in merged images. However, EPO prevents nuclear translocation of FoxO3a by retaining FoxO3a in the cytoplasm similar to control cells with nuclei visible in merged images and indicated by the white arrows.

necrosis factor- $\alpha(\mathrm{TNF} \alpha),{ }^{108}$ interleukin- $1 \beta(\mathrm{IL}-1 \beta)$ and interleukin-6 (IL-6) ${ }^{109}$ also can lead to increased expression of EPO and the $\mathrm{EPOR}^{73,74}$ and may provide a feed-back loop that is regulated by EPO such as TNF $\alpha .{ }^{110}$

\section{FoxO Transcription Factors}

FoxO proteins and their regulation. Mammalian forkhead transcription factors of the $\mathrm{O}$ class (FoxOs) function to either block or activate target gene expression. ${ }^{11}$ At least 100 forkhead genes and 19 human subgroups that range from FOXA to FOXS are now known to exist since the initial discovery of the fly Drosophila melanogaster gene forkhead. ${ }^{112}$ The original nomenclature for these proteins, such as forkhead in rhabdomyosarcoma (FKHR), the Drosophila gene fork head $(f k h)$ and Forkhead RElated ACtivator (FREAC) -1 and -2, has been replaced. ${ }^{113}$ The current nomenclature for human Fox proteins places all letters in uppercase, otherwise only the initial letter is listed as uppercase for the mouse, and for all other chordates the initial and subclass letters are in uppercase. ${ }^{114}$

FoxO proteins also may function as biomarkers. The activation of FoxO transcription factors during tumor invasion may suggest the initiation of cell pathways that are attempting to restrict neoplastic growth and represent a positive prognostic factor. ${ }^{111,115,116}$ However, reliance on any single biomarker may be imperfect and lead to initially unpredicted outcome ${ }^{78,79,117}$ or the onset of detrimental apoptotic programs with forkhead transcription factors. ${ }^{30} \mathrm{~A}$ number of other pathways that occur in combination with a particular biomarker during oxidative stress also may also influence outcome. In the case of breast cancer, studies suggests that the release of androgens, cytokines or even changes in body mass and exercise can influence outcome as well as alter the predictability of a specific biomarker. ${ }^{118,119}$

FoxO proteins (FoxO1, FoxO3, FoxO4 and FoxO6) are present throughout the body and are expressed in tissues of the reproductive system of males and females, skeletal muscle, the cardiovascular system, lung, liver, pancreas, spleen, thymus and the nervous system. ${ }^{105,111,115,116,120-127}$ Post-translational control of FoxO proteins employs pathways associated with ubiquitylation and acetylation. ${ }^{128,129}$ IКB kinase (IKK) can phosphorylate and block the activity of FoxO proteins, such as FoxO3a. ${ }^{113,115}$ This leads to the proteolysis of FoxO3a via the Ubdependent proteasome pathway. ${ }^{113,115,126,130,131}$ FoxOs also are acetylated by histone acetyltransferases that include p300, the CREB-binding protein $(\mathrm{CBP})$, and the CBP-associated factor. FoxO proteins are deacetylated by histone deacetylases. ${ }^{115}$

In addition to acetylation, and ubiquitylation, post-translational modulation of FoxO proteins also involves pathways 
associated with phosphorylation. ${ }^{113,115,126,130,131}$ Protein phosphorylation is a critical pathway in the scheme for protein regulation. ${ }^{132}$ Akt is a primary mediator of phosphorylation of FoxO1, FoxO3a and FoxO4 that can block activity of these proteins. ${ }^{113,133}$ Akt phosphorylation of FoxO proteins not only retains these transcription factors in the cytoplasm, but also leads to ubiquitination and degradation through the $26 \mathrm{~S}$ proteasome. ${ }^{129,130}$ Interestingly, activation of Akt in pathways that involve EPO or FoxOs is usually cytoprotective, but may mediate other processes. For example, Akt either alone or through EPO can lead to cell proliferation, ${ }^{134}$ blood-brain barrier permeability, ${ }^{135}$ or cell protection during inflammation, ${ }^{136,137}$ neurodegeneration, ${ }^{138}$ hyperglycemia, ${ }^{139}$ hypoxia, ${ }^{80} \mathrm{~A} \beta$ toxicity, ${ }^{45,140-143}$ excitotoxicity, ${ }^{144}$ cardiomyopathy, ${ }^{145}$ cellular aging ${ }^{146}$ and oxidative stress. ${ }^{24,26,36}$ In addition, Akt can prevent cellular apoptosis through the phosphorylation of FoxO proteins. ${ }^{5}$ Posttranslational phosphorylation of FoxOs, such as during EPO administration, will maintain FoxO transcription factors in the cytoplasm by association with 14-3-3 proteins and prevent the transcription of pro-apoptotic target genes $^{74,81}$ (Fig. 1).

Modulation of Akt activity also controls apoptotic pathways of caspases that may offer an alternative mechanism to regulate FoxO proteins. ${ }^{116}$ Caspases are a family of cysteine proteases that are synthesized as inactive zymogens that are proteolytically cleaved into subunits at the onset of apoptosis. ${ }^{38,147,148}$ The caspases 1 and 3 have been linked to the apoptotic pathways of genomic DNA cleavage, cellular membrane PS exposure and activation of inflammatory cells. ${ }^{40,56,63}$ Caspase pathways may be tied to the forkhead transcription factor FoxO3a since increased activity of FoxO3a can result in cytochrome $c$ release and caspaseinduced apoptotic death. ${ }^{81,149-151}$ Pathways that can inhibit caspase 3 appear to offer a unique regulatory mechanism. For example, studies suggests that cell death pathways that rely upon FoxO3a also appear to involve caspase 3 activation. ${ }^{46}$ FoxO3a activity promotes caspase-induced apoptotic death, ${ }^{81,149-151}$ but inhibition of caspase 3 also can maintain the phosphorylated "inactive" state of FoxO3a to prevent cell injury. ${ }^{81,149,150}$ Other work has shown that caspase 3 activity and cleavage is promoted during transfection of a triple mutant FoxO3a expression in which three phosphorylation sites have been altered to prevent inactivation of FoxO3a. ${ }^{152}$ Furthermore, FoxO3a may control early activation and subsequent apoptotic injury in microglia during $A \beta$ exposure through caspase $3 .{ }^{46}$ Since $A \beta$ exposure can facilitate the cellular trafficking of FoxO3a from the cytoplasm to the cell nucleus to potentially lead to "pro-apoptotic" programs by this transcription factor, ${ }^{46}$ one program in particular that may be vital for apoptotic injury appears to involve the activation of caspase 3 . A $\beta$ exposure leads to a rapid and significant increases in caspase 3 activity with 6 hours following $A \beta$ administration, but that this induction of caspase 3 activity by $\mathrm{A} \beta$ requires FoxO3a, since loss of FoxO3a through gene silencing prevents the induction of caspase 3 activity by $A \beta$.

\section{EPO, FoxOs, Nervous System Metabolism and Cognitive Impairment}

Both EPO and FoxOs play a significant role during brain metabolism and metabolic disorders that can alter the progression of $\mathrm{AD}$, such as during diabetes mellitus (DM). DM is a significant health concern for both young and older populations. ${ }^{153,154}$ Patients with DM can develop immune dysfunction, ${ }^{155}$ cognitive disorders, ${ }^{155,156}$ hepatic dysfunction, ${ }^{157}$ renal disease, ${ }^{158}$ hematological disease, ${ }^{159}$ neurodegenerative disorders ${ }^{4,105,160}$ and cardiovascular disease. ${ }^{160,161}$ Interestingly, the development of insulin resistance and the complications of DM can be the result of cellular oxidative stress. ${ }^{153,160}$ Furthermore, acute glucose swings in addition to chronic hyperglycemia can trigger oxidative stress mechanisms, illustrating the importance for therapeutic interventions during acute and sustained hyperglycemic episodes. ${ }^{153,160}$

In regards to EPO during metabolic disorders, EPO administration has been shown both in diabetics as well as non-diabetics with severe, resistant congestive heart failure to decrease fatigue, increase left ventricular ejection fraction, and significantly decrease the number of hospitalization days. ${ }^{162}$ In vitro studies with vascular cells exposed to elevated glucose also have demonstrated that EPO can significantly improve EC survival in a $1.0 \mathrm{ng} / \mathrm{ml}$ range. ${ }^{163} \mathrm{EPO}$ administration in patients also can significantly increase plasma levels of EPO well above this range of $1.0 \mathrm{ng} / \mathrm{ml}$ that has been associated with potential EPO cellular protection in patients with cardiac or renal disease, ${ }^{164,165}$ suggesting that the effects of EPO observed during in vitro studies may parallel the cellular processes altered by EPO in patients with metabolic disorders. ${ }^{92}$ Furthermore, EPO during elevated glucose and similar to other models of oxidative stress can block neuronal degeneration ${ }^{166}$ and apoptotic DNA degradation in ECs in vascular cell models. ${ }^{63,80,81,83,167}$ Protection by EPO also is related to the maintenance of mitochondrial membrane potential $\left(\Delta \Psi_{\mathrm{m}}\right)$. Loss of $\Delta \Psi_{\mathrm{m}}$ through the opening of the mitochondrial permeability transition pore represents a significant determinant for cell injury and the subsequent induction of apoptosis. ${ }^{22,65}$ EPO has the capacity to prevent the depolarization of the mitochondrial membrane that also affects the release of cytochrome $c .^{47,80,168}$

Additional work suggests that proteins derived from the Drosophila Wingless $(\mathrm{Wg})$ and the mouse Int-1 genes may be associated with cellular metabolic complications. ${ }^{30}$ The Wnt proteins are secreted cysteine-rich glycosylated proteins that can control cell proliferation, ${ }^{169,170}$ differentiation, survival and tumorigenesis. ${ }^{39,171}$ These genes are present in several cellular populations ${ }^{172}$ such as neurons, cardiomyocytes, endothelial cells, cancer cells and preadipocytes. ${ }^{4}$ Abnormalities in the Wnt pathway, such as with transcription factor 7-like 2 gene, may impart increased risk for type 2 diabetes in some populations ${ }^{173-175}$ as well as have increased association with obesity. ${ }^{176}$ Yet, intact Wnt family members may offer glucose tolerance and increased insulin sensitivity ${ }^{177}$ as well as protect glomerular mesangial cells from elevated glucose induced apoptosis. ${ }^{178}$ These observations suggest a potential protective cellular mechanism for EPO through Wnt signaling. Cell culture studies demonstrate that the Wnt1 protein is necessary and sufficient to impart cellular protection 
during elevated glucose exposure. ${ }^{163}$ EPO maintains the expression of Wnt1 during elevated glucose exposure and prevents loss of Wnt1 expression that would occur in the absence of EPO during elevated glucose. In addition, blockade of Wnt1 with a Wnt1 antibody can neutralize the protective capacity of EPO, illustrating that Wnt1 is a critical component in the cytoprotection of EPO during elevated glucose exposure. ${ }^{163}$

In regards to FoxO proteins, analysis of the genetic variance in FOXOIa and FOXO3a on metabolic profiles, age-related diseases, fertility, fecundity and mortality in patients have observed higher $\mathrm{HbA}_{1 \mathrm{c}}$ levels and increased mortality risk associated with specific haplotypes of FOXO1a ${ }^{179}$ These clinical observations may coincide with the demonstration in human endothelial progenitor cells that elevated glucose levels can reduce post-translational phosphorylation of FOXO1, FOXO3a and FOXO4 and allow for the nuclear translocation of these proteins to initiate an apoptotic program in endothelial progenitor cells. ${ }^{180}$ In experimental models, FoxO proteins may prevent the toxic effects of high serum glucose levels. ${ }^{13,115}$ Interferon-gamma driven expression of tryptophan catabolism by cytotoxic T lymphocyte antigen 4 may activate Foxo3a to protect dendritic cells from injury in nonobese diabetic mice. ${ }^{181}$ Additional studies have demonstrated that adipose tissue-specific expression of Foxol in mice improved glucose tolerance and sensitivity to insulin during an elevated fat diet. ${ }^{182}$ FoxO proteins also may protect against diminished mitochondrial energy levels known to occur during insulin resistance such as in the elderly populations. ${ }^{153,154,160}$ In caloric restricted mice that have decreased energy reserves, Foxo1, Foxo3a and Foxo4 mRNA levels were noted to progressively increase over a two year course. ${ }^{122}$ These observations complement studies in Drosophila and mammalian cells that demonstrate an increase in insulin signaling to regulate cellular metabolism during the upregulation of FoxO1 expression. ${ }^{183}$

It should be noted that the ability for FoxO proteins to maintain proper physiologic controls over cellular metabolism might be limited and occur only during specific circumstances. For example, mice with a constitutively active Foxol transgene have increased microsomal triglyceride transfer protein and elevated plasma triglyceride levels. ${ }^{184}$ Studies in cardiomyocytes also suggest detrimental results with enhanced FoxO activity. Increased transcriptional activity of FoxO1, such as by the Sirt1 activator resveratrol, can diminish insulin mediated glucose uptake and result in insulin resistance. ${ }^{185}$ Overexpression of Foxol in skeletal muscles of mice also can lead to reduced skeletal muscle mass and poor glycemic control, ${ }^{186}$ illustrating that activation of FoxO proteins also may impair cellular energy reserves. Other studies that block the expression of Foxol in normal and cachectic mice $^{187}$ or reduce $\mathrm{FoxO} 3$ expression ${ }^{188}$ show the reverse with an increase in skeletal muscle mass or resistance to muscle atrophy. With this in mind, one potential agent to consider for the maintenance of cellular metabolism in patients is nicotinamide, ${ }^{13,38}$ an agent that also can inhibit FoxO protein activity. ${ }^{150}$ In patients with $\mathrm{DM}$, oral nicotinamide protects $\beta$-cell function, prevents clinical disease in islet-cell antibody-positive first-degree relatives of type-1 DM, and can reduce $\mathrm{HbA}_{1 \mathrm{c}}$ levels. ${ }^{13,38,153}$ Nicotinamide, which is closely linked to cell longevity pathways, ${ }^{189,190}$ may derive its protective capacity through two separate mechanisms of posttranslational modification of FoxO3a. Nicotinamide not only can maintain phosphorylation of $\mathrm{FoxO} 3 \mathrm{a}$ and inhibit its activity, but also preserve FoxO3a integrity to block FoxO3a proteolysis that can yield pro-apoptotic amino-terminal fragments. ${ }^{150}$

\section{EPO, FoxOs and Neurovascular Survival}

EPO and FoxO proteins can directly govern cell survival that can affect the progression of $\mathrm{AD}$ and cognitive loss. With EPO, it can prevent cell injury during $\mathrm{AD}$ and $\mathrm{A} \beta$ cell injury, ${ }^{45,143,191,192}$ hypoxia, ${ }^{40,80,193-196}$ excitotoxicity, ${ }^{197-199}$ parasitic disease, ${ }^{200-202}$ endotoxin shock, ${ }^{203,204}$ free radical exposure, ${ }^{47,63,198}$ cardiac disease, ${ }^{205,206}$ amyloid toxicity ${ }^{143,192}$ and pulmonary disease. ${ }^{207,208}$ EPO also represents a potential option for the prevention of retinal degeneration or neovascularization ${ }^{209-212}$ as well as glaucoma. ${ }^{213}$ In the CNS, systemic application of EPO also can improve functional outcome and reduce cell loss during spinal cord injury, ${ }^{214,215}$ traumatic cerebral edema, ${ }^{216}$ cortical trauma ${ }^{217}$ and epileptic activity. ${ }^{82,218,219}$

EPO also can reduce cytokine gene expression in endothelial cells exposed to tumor necrosis factor, ${ }^{167}$ prevent ulcer progression in cases of scleroderma, ${ }^{220}$ reduce inflammation in murine arthritis models, ${ }^{221}$ and block primary microglial activation and proliferation ${ }^{24,26,33}$ during oxidative stress ${ }^{40,143}$ to prevent phagocytosis of injured cells through pathways that involve cellular membrane PS exposure, protein kinase $\mathrm{B},{ }^{24}$ and the regulation of caspases. ${ }^{40,63,222} \mathrm{EPO}$ can directly inhibit several pro-inflammatory cytokines, such as IL-6, TNF $\alpha$ and monocyte chemoattractant protein $1,{ }^{74,223}$ and reduce leukocyte inflammation. ${ }^{224}$ EPO also may foster the preservation of microglial cells for neuronal and vascular restructuring by preventing apoptotic injury in microglia. ${ }^{34,225}$

In contrast to EPO cytoprotection, FoxO transcription factors usually lead to apoptosis during oxidative stress. ${ }^{5}$ For example, forkhead transcription factors such as FoxO1 and FoxO3a must be present for oxidative stress to result in apoptotic cell injury. ${ }^{226}$ FoxO3a in conjunction with JNK also has been shown to modulate an apoptotic ligand activating a Fasmediated death pathway in cultured motoneurons, ${ }^{227}$ to lead to apoptosis through tumornecrosis-factor-related apoptosis-inducing ligand (TRAIL) and $\mathrm{BH} 3$-only proteins Noxa and Bim in neuroblastoma cells, ${ }^{151}$ and to promote pro-apoptotic activity of $\mathrm{p} 53 .{ }^{228}$ In addition, loss of FoxO expression during oxidative stress is protective to cells. Protein inhibition or gene knockdown of FoxO1 or FoxO3a can lead to reduction in ischemic infarct size in the brain, ${ }^{229}$ mediate protection of metabotropic glutamate receptors during vascular injury, ${ }^{149}$ enhance pancreatic $\beta$-cell or neuronal survival through $\mathrm{NAD}^{+}$precursors during oxidative stress ${ }^{150}$ and provide trophic factor protection with $\mathrm{EPO}^{81}$ and neurotrophins. ${ }^{230}$

Furthermore, similar to pathways tied to EPO and Wnt, the canonical Wnt pathway ${ }^{231,232}$ that involves $\beta$-catenin ${ }^{39,171}$ also appears to link FoxO proteins and Wnt signaling together. ${ }^{30}$ For example, in relation to $\mathrm{AD},{ }^{233} \mathrm{~A} \beta$ is toxic to cells $s^{45,143,234}$ and is associated with the phosphorylation of FoxO1 and FoxO3a that can be blocked with ROS scavengers. ${ }^{235} \mathrm{~A}$ common denominator 
in the pathways linked to $A \beta$ toxicity involves Wnt signaling ${ }^{45,236}$ and $\beta$-catenin. $\beta$-catenin may increase FoxO transcriptional activity and competitively limit $\beta$-catenin interaction with members of the lymphoid enhancer factor/T cell factor family. ${ }^{237}$ This may lead to cell injury, since $\beta$-catenin has been demonstrated to be necessary for protection against $A \beta$ toxicity in neuronal cells. ${ }^{45}$

However, not all conditions with FoxOs may lead to cell demise. Some studies suggest that the loss of FoxO1, FoxO3a and FoxO4 protein expression may actually lead to an increase in free radical release that can be responsible for oxidative stress. ${ }^{238}$ In addition, FoxO proteins also may influence early apoptotic membrane PS externalization. ${ }^{25,34}$ The ability to regulate early apoptotic membrane PS exposure ${ }^{40}$ and inflammatory cell activity $^{26}$ can ultimately affect cell survival since activated immune cells can lead to the phagocytic removal of injured cells. ${ }^{33,59}$ Furthermore, FoxO proteins may be protective during aging and exercise, since FoxO3a activity may enhance vascular smooth muscle antioxidant properties in aged animals and be beneficial to the cardiovascular system during physical exertion. ${ }^{239}$

\section{Future Perspectives}

As biomarkers for disease onset and progression as well as candidates for the treatment of numerous disorders, EPO and FoxO transcription factors generate excitement for the potential to yield new strategies for the treatment of neurovascular injury and cognitive disorders. Yet, some considerations for EPO exist. In addition to the problems associated with EPO abuse and gene doping, ${ }^{240-242}$ EPO has been correlated with the alteration of red cell membrane properties leading to a cognitive decrement in rodent animal models. ${ }^{73,74,223}$ Development of potentially detrimental side-effects during EPO therapy, such as for cerebral ischemia with increased metabolic rate and blood viscosity, ${ }^{243}$ could also severely limit the use of EPO for neurovascular diseases. As a result, alternate strategies have been suggested. New proposals examine the role of targeted bioavailability for EPO such as in bone marrow stromal cells genetically engineered to secrete $\mathrm{EPO}^{244}$ and controlled release of EPO from encapsulated cells. ${ }^{245,246}$ The passage of EPO entry into the CNS continues to attract significant interest ${ }^{247}$ as well as does the use of novel intranasal routes for EPO administration. ${ }^{196}$ The development of derivations of EPO to reduce erythropoietic activity and the potential associated vascular complications ${ }^{197}$ have also been put forth as new directions for treatment. Yet, these lines of investigation are not without limitations, since chemical derivatives of EPO can become absent of clinical efficacy ${ }^{73,74}$ as well as possibly loose the ability to promote sustainable cytoprotective effects, such as neurogenesis ${ }^{248}$ and angiogenesis. ${ }^{249-252}$

Other work also offers additional support for the use of FoxO proteins as biomarkers of neurovascular injury that can occur during $\mathrm{AD}$ and cognitive loss. Down regulation of the phosphatidylinositol 3 kinase and Akt pathways have been associated with increased transcript levels for FOXO1a and FOXO3a in cell loss scenarios. ${ }^{253}$ The known mutations in FoxO proteins that exist in several disease entities may provide novel insights for the new treatment strategies. Future analysis in larger populations of patients with metabolic disease and cognitive loss could strengthen our understanding of the role of FoxO proteins in these disorders. In addition, targeting the activity of FoxO1, FoxO3a or FoxO4 in vascular cells may prevent the onset of pathological neointimal hyperplasia that may result in atherosclerosis and cognitive loss. Recent studies also suggest that the utilization and combination of multiple biomarkers may improve risk assessment for patients suffering from a number of disorders. ${ }^{254}$ These studies illustrate that FoxO proteins may serve as biomarkers of disease activity such as in individualswith imminent cardiac failure. ${ }^{255}$

As combined therapeutic entities and biomarkers, EPO and FoxO proteins share a number of pathways to offer novel therapeutic strategies for a broad range of disorders. Future studies that involve basic research as well as clinical trials are warranted for EPO and FoxO proteins. Yet, critical to this process is the clear focus upon the intricate cellular pathways governed by EPO and FoxOs to uncover the benefits and risks of these agents for development of proper therapies to prevent the onset or progression of $\mathrm{AD}$ and cognitive loss.

\section{Acknowledgements}

We apologize to our colleagues whose work we were unable to cite as a result of article space limitations. This research was supported by the following grants to K.M.: American Diabetes Association, American Heart Association (National), Bugher Foundation Award, Janssen Neuroscience Award, LEARN Foundation Award, MI Life Sciences Challenge Award, Nelson Foundation Award, NIH NIEHS (P30 ES06639), NIH NIA and NIH NINDS.

\section{References}

1. Mendiondo MS, Kryscio RJ, Schmitt FA. Models of progression in $\mathrm{AD}$ : predicting disability and costs. Neurology 2001; 57:943-4.

2. McCormick WC, Hardy J, Kukull WA, Bowen JD, Teri L, Zitzer S, et al. Healthcare utilization and costs in managed care patients with Alzheimer's disease during the last few years of life. J Am Geriatr Soc 2001; 49:1156-60.

3. Chong ZZ, Li F, Maiese K. Oxidative stress in the brain: Novel cellular targets that govern survival during neurodegenerative disease. Prog Neurobiol 2005; 75:207-46.

4. Maiese K. Triple play: Promoting neurovascular longevity with nicotinamide, WNT and erythropoietin in diabetes mellitus. Biomed Pharmacother 2008; 62:218-32.
5. Maiese K, Chong ZZ, Hou J, Shang YC. Erythropoietin and oxidative stress. Curr Neurovasc Res 2008; 5:125-42.

6. Regulska M, Leskiewicz M, Budziszewska B, Kutner A, Jantas D, Basta-Kaim A, et al. Inhibitory effects of 1,25-dihydroxyvitamin $\mathrm{D}(3)$ and its low-calcemic analogues on staurosporine-induced apoptosis. Pharmacol Rep 2007; 59:393-401.

7. Chlopicki S, Swies J, Mogielnicki A, Buczko W, Bartus M, Lomnicka M, et al. 1-Methylnicotinamide (MNA), a primary metabolite of nicotinamide, exerts anti-thrombotic activity mediated by a cyclooxygenase-2/prostacyclin pathway. Br J Pharmacol 2007; 152:230-9.

8. Chong ZZ, Lin SH, Maiese K. Nicotinamide Modulates Mitochondrial Membrane Potential and Cysteine Protease Activity during Cerebral Vascular Endothelial Cell Injury. J Vasc Res 2002; 39:131-47.
9. Feng Y, Paul IA, LeBlanc MH. Nicotinamide reduces hypoxic ischemic brain injury in the newborn rat. Brain Res Bull 2006; 69:117-22.

10. Hara N, Yamada K, Shibata T, Osago H, Hashimoto T, Tsuchiya M. Elevation of cellular NAD levels by nicotinic acid and involvement of nicotinic acid phosphoribosyltransferase in human cells. J Biol Chem 2007; 282:24574-82.

11. Ieraci A, Herrera DG. Nicotinamide Protects against Ethanol-Induced Apoptotic Neurodegeneration in the Developing Mouse Brain. PLoS Med 2006; $3: 101$

12. Lin SH, Vincent A, Shaw T, Maynard KI, Maiese K. Prevention of nitric oxide-induced neuronal injury through the modulation of independent pathways of programmed cell death. J Cereb Blood Flow Metab 2000; 20:1380-91. 
13. Maiese K, Chong ZZ. Nicotinamide: necessary nutrient emerges as a novel cytoprotectant for the brain. Trends Pharmacol Sci 2003; 24:228-32.

14. Chong ZZ, Li F, Maiese K. Attempted Cell Cycle Induction in Post-Mitotic Neurons Occurs in Early and Late Apoptotic Programs Through Rb, E2F1 and Caspase 3. Curr Neurovasc Res 2006; 3:25-39.

15. De Felice FG, Velasco PT, Lambert MP, Viola K, Fernandez SJ, Ferreira ST, et al. Abeta oligomers induce neuronal oxidative stress through an $\mathrm{N}$-methyl-D-aspartate receptor-dependent mechanism that is blocked by the Alzheimer drug memantine. J Biol Chem 2007; 282:11590-601.

16. Lin SH, Maiese K. The metabotropic glutamate receptor system protects against ischemic free radical programmed cell death in rat brain endothelial cells. J Cereb Blood Flow Metab 2001; 21:262-75.

17. He XL, Wang YH, Gao M, Li XX, Zhang TT, $\mathrm{Du}$ GH. Baicalein protects rat brain mitochondria against chronic cerebral hypoperfusion-induced oxidative damage. Brain Res 2009; 1249:212-21.

18. Maiese K, Chong ZZ, Shang YC, Hou J. Therapeutic promise and principles: Metabotropic glutamate receptors. Oxid Med Cell Longev 2008; 1:1-14.

19. Plecita-Hlavata L, Lessard M, Santorova J, Bewersdorf J, Jezek P. Mitochondrial oxidative phosphorylation and energetic status are reflected by morphology of mitochondrial network in INS-1E and HEP-G2 cells viewed by $4 \mathrm{Pi}$ microscopy. Biochim Biophys Acta 2008; 1777:834-46

20. Chong ZZ, Li F, Maiese K. Stress in the brain: novel cellular mechanisms of injury linked to Alzheimer's disease. Brain Res Brain Res Rev 2005; 49:1-21.

21. Harris SE, Fox H, Wright AF, Hayward C, Starr JM, Whalley LJ, et al. A genetic association analysis of cognitive ability and cognitive ageing using 325 markers for 109 genes associated with oxidative stress or cognition. BMC Genet 2007; 8:43.

22. Leuner K, Hauptmann S, Abdel-Kader R, Scherping I, Keil U, Strosznajder JB, et al. Mitochondrial dysfunction: the first domino in brain aging and Alzheimer's disease? Antioxid Redox Signal 2007; 9:1659-75.

23. Okouchi M, Ekshyyan O, Maracine M, Aw TY. Neuronal apoptosis in neurodegeneration. Antioxid Redox Signal 2007; 9:1059-96.

24. Chong ZZ, Kang JQ, Maiese K. Akt1 drives endothelial cell membrane asymmetry and microglial activation through $\mathrm{Bcl}-\mathrm{x}(\mathrm{L})$ and caspase 1, 3 and 9. Exp Cell Res 2004; 296:196-207.

25. Chong ZZ, Li F, Maiese K. The pro-survival pathways of mTOR and protein kinase B target glycogen synthase kinase-3beta and nuclear factor-kappaB to foster endogenous microglial cell protection. Int J Mol Med 2007; 19:263-72.

26. Kang JQ, Chong ZZ, Maiese K. Critical role for Akt1 in the modulation of apoptotic phosphatidylserine exposure and microglial activation. Mol Pharmacol 2003; 64:557-69.

27. Karunakaran S, Diwakar L, Saeed U, Agarwal V, Ramakrishnan S, Iyengar S, et al. Activation of apoptosis signal regulating kinase 1 (ASK1) and translocation of death-associated protein, Daxx, in substantia nigra pars compacta in a mouse model of Parkinson's disease: protection by alpha-lipoic acid. Faseb J 2007; 21:2226-36.

28. Verdaguer E, Susana Gde A, Clemens A, Pallas M, Camins A. Implication of the transcription factor E2F-1 in the modulation of neuronal apoptosis. Biomed Pharmacother 2007; 61:390-9.

29. Chong ZZ, Li F, Maiese K. Employing new cellular therapeutic targets for Alzheimer's disease: a change for the better? Curr Neurovasc Res 2005; 2:55-72.

30. Maiese K, Chong ZZ, Shang YC, Hou J. Rogue proliferation versus restorative protection: where do we draw the line for Wnt and forkhead signaling? Expert opinion on therapeutic targets 2008; 12:905-16.
31. Maiese K, Vincent A, Lin SH, Shaw T. Group I and Group III metabotropic glutamate receptor subtype provide enhanced neuroprotection. J Neurosci Res 2000; 62:257-72.

32. Mari C, Karabiyikoglu M, Goris ML, Tait JF, Yenari MA, Blankenberg FG. Detection of focal hypoxicischemic injury and neuronal stress in a rodent model of unilateral MCA occlusion/reperfusion using radiolabeled annexin V. Eur J Nucl Med Mol Imaging 2004; 31:733-9.

33. Chong ZZ, Kang J, Li F, Maiese K. mGluRI Targets Microglial Activation and Selectively Prevents Neuronal Cell Engulfment Through Akt and Caspase Dependent Pathways. Curr Neurovasc Res 2005; 2:197-211.

34. Li F, Chong ZZ, Maiese K. Microglial integrity is maintained by erythropoietin through integration of Akt and its substrates of glycogen synthase kinase3 beta, beta-catenin and nuclear factor-kappaB. Curr Neurovasc Res 2006; 3:187-201.

35. Chong ZZ, Kang JQ, Maiese K. Metabotropic glutamate receptors promote neuronal and vascular plasticity through novel intracellular pathways. Histol Histopathol 2003; 18:173-89.

36. Kang JQ, Chong ZZ, Maiese K. Akt1 protects against inflammatory microglial activation through maintenance of membrane asymmetry and modulation of cysteine protease activity. J Neurosci Res 2003; 74:37-51.

37. Mallat M, Marin-Teva JL, Cheret C. Phagocytosis in the developing CNS: more than clearing the corpses. Curr Opin Neurobiol 2005; 15:101-7.

38. Li F, Chong ZZ, Maiese K. Cell Life Versus Cell Longevity: The Mysteries Surrounding the NAD (+) Precursor Nicotinamide. Curr Med Chem 2006; 13:883-95.

39. Li F, Chong ZZ, Maiese K. Winding through the WNT pathway during cellular development and demise. Histol Histopathol 2006; 21:103-24.

40. Chong ZZ, Kang JQ, Maiese K. Erythropoietin fosters both intrinsic and extrinsic neuronal protection through modulation of microglia, Akt1, Bad and caspase-mediated pathways. Br J Pharmacol 2003. 138:1107-18

41. Lin SH, Chong ZZ, Maiese K. Cell cycle induction in post-mitotic neurons proceeds in concert with the initial phase of programmed cell death in rat. Neurosci Lett 2001; 310:173-7.

42. Maiese K. The dynamics of cellular injury: transformation into neuronal and vascular protection. Histol Histopathol 2001; 16:633-44.

43. Maiese K, Ahmad I, TenBroeke M, Gallant J. Metabotropic glutamate receptor subtypes independently modulate neuronal intracellular calcium. J Neurosci Res 1999; 55:472-85.

44. Vincent AM, Maiese K. Direct temporal analysis of apoptosis induction in living adherent neurons. J Histochem Cytochem 1999; 47:661-72.

45. Chong ZZ, Li F, Maiese K. Cellular demise and inflammatory microglial activation during betaamyloid toxicity are governed by Wnt 1 and canonical signaling pathways. Cell Signal 2007; 19:1150-62.

46. Shang YC, Chong ZZ, Hou J, Maiese K. The forkhead transcription factor FoxO3a controls microglial inflammatory activation and eventual apoptotic injury through caspase 3. Curr Neurovasc Res 2009; $6: 20-31$.

47. Chong ZZ, Lin SH, Kang JQ, Maiese K. Erythropoietin prevents early and late neuronal demise through modulation of Akt1 and induction of caspase 1, 3 and 8. J Neurosci Res 2003; 71:65969.

48. Chong ZZ, Lin SH, Kang JQ, Maiese K. The tyrosine phosphatase SHP2 modulates MAP kinase p38 and caspase 1 and 3 to foster neuronal survival. Cell Mol Neurobiol 2003; 23:561-78.
49. Maiese K, Boccone L. Neuroprotection by peptide growth factors against anoxia and nitric oxide toxicity requires modulation of protein kinase C. J Cereb Blood Flow Metab 1995; 15:440-9.

50. Maiese K, Boniece IR, Skurat K, Wagner JA. Protein kinases modulate the sensitivity of hippocampal neurons to nitric oxide toxicity and anoxia. J Neurosci Res 1993; 36:77-87.

51. Maiese K, TenBroeke M, Kue I. Neuroprotection of lubeluzole is mediated through the signal transduction pathways of nitric oxide. J Neurochem 1997; 68:710-4.

52. Salinas M, Diaz R, Abraham NG, Ruiz de Galarreta CM, Cuadrado A. Nerve growth factor protects against 6-hydroxydopamine-induced oxidative stress by increasing expression of heme oxygenase- 1 in a phosphatidylinositol 3-kinase-dependent manner. J Biol Chem 2003; 278:13898-904.

53. Leytin V, Allen DJ, Mykhaylov S, Lyubimov E, Freedman J. Thrombin-triggered platelet apoptosis. J Thromb Haemost 2006; 4:2656-63.

54. Maiese K, Vincent AM. Critical temporal modulation of neuronal programmed cell injury. Cell Mol Neurobiol 2000; 20:383-400.

55. Maiese K, Vincent AM. Membrane asymmetry and DNA degradation: functionally distinct determinants of neuronal programmed cell death. J Neurosci Res 2000; 59:568-80.

56. Chong ZZ, Kang JQ, Maiese K. Essential cellular regulatory elements of oxidative stress in early and late phases of apoptosis in the central nervous system. Antioxid Redox Signal 2004; 6:277-87.

57. Dombroski D, Balasubramanian K, Schroit AJ. Phosphatidylserine expression on cell surfaces promotes antibody-dependent aggregation and thrombosis in beta2-glycoprotein Iimmune mice. J Autoimmun 2000; 14:221-9.

58. Jessel R, Haertel S, Socaciu C, Tykhonova S, Diehl HA. Kinetics of apoptotic markers in exogeneously induced apoptosis of EL4 cells. J Cell Mol Med 2002; 6:82-92.

59. Chong ZZ, Maiese K. The Src homology 2 domain tyrosine phosphatases SHP-1 and SHP-2: diversified control of cell growth, inflammation and injury. Histol Histopathol 2007; 22:1251-67.

60. Vincent AM, Maiese K. Nitric oxide induction of neuronal endonuclease activity in programmed cell death. Exp Cell Res 1999; 246:290-300.

61. Vincent AM, TenBroeke M, Maiese K. Metabotropic glutamate receptors prevent programmed cell death through the modulation of neuronal endonuclease activity and intracellular pH. Exp Neurol 1999; 155:79-94.

62. Di Lisa F, Menabo R, Canton M, Barile M, Bernardi P. Opening of the mitochondrial permeability transition pore causes depletion of mitochondrial and cytosolic $\mathrm{NAD}^{+}$and is a causative event in the death of myocytes in postischemic reperfusion of the heart. J Biol Chem 2001; 276:2571-5.

63. Chong ZZ, Kang JQ, Maiese K. Apaf-1, Bcl- $x_{\mathrm{L}}$, Cytochrome $c$ and Caspase-9 Form the Critical Elements for Cerebral Vascular Protection by Erythropoietin. J Cereb Blood Flow Metab 2003; 23:320-30.

64. Chong ZZ, Lin SH, Li F, Maiese K. The sirtuin inhibitor nicotinamide enhances neuronal cell survival during acute anoxic injury through Akt, Bad, PARP and mitochondrial associated "anti-apoptotic" pathways. Curr Neurovasc Res 2005; 2:271-85.

65. Maiese K, Chong ZZ. Insights into oxidative stress and potential novel therapeutic targets for Alzheimer disease. Restor Neurol Neurosci 2004; 22:87-104.

66. Li F, Chong ZZ, Maiese K. Navigating novel mechanisms of cellular plasticity with the $\mathrm{NAD}^{+}$precursor and nutrient nicotinamide. Front Biosci 2004; 9:2500-20. 
67. Wilson FH, Hariri A, Farhi A, Zhao H, Petersen KF, Toka HR, et al. A cluster of metabolic defects caused by mutation in a mitochondrial tRNA. Science 2004; 306:1190-4.

68. Roberts E Jr, Chih CP. The influence of age of $\mathrm{pH}$ regulation in hippocampal slices before, during and after anoxia. J Cereb Blood Flow Metab 1997; 17:560-6.

69. Cardella F. Insulin therapy during diabetic ketoacidosis in children. Acta Biomed 2005; 76:49-54.

70. Kratzsch J, Knerr I, Galler A, Kapellen T, Raile K, Korner A, et al. Metabolic decompensation in children with type 1 diabetes mellitus associated with increased serum levels of the soluble leptin receptor. Eur J Endocrinol 2006; 155:609-14.

71. Ito N, Bartunek J, Spitzer KW, Lorell BH. Effects of the nitric oxide donor sodium nitroprusside on intracellular $\mathrm{pH}$ and contraction in hypertrophied myocytes. Circulation 1997; 95:2303-11.

72. Vincent AM, TenBroeke M, Maiese K. Neuronal intracellular $\mathrm{pH}$ directly mediates nitric oxideinduced programmed cell death. J Neurobiol 1999; 40:171-84.

73. Maiese K, Li F, Chong ZZ. Erythropoietin in the brain: can the promise to protect be fulfilled? Trends Pharmacol Sci 2004; 25:577-83.

74. Maiese K, Li F, Chong ZZ. New avenues of exploration for erythropoietin. JAMA 2005; 293:90-5.

75. Fliser D, Haller H. Erythropoietin and treatment of non-anemic conditions-cardiovascular protection. Semin Hematol 2007; 44:212-7.

76. Teramo KA, Widness JA. Increased fetal plasma and amniotic fluid erythropoietin concentrations: markers of intrauterine hypoxia. Neonatology 2009; 95:105-16.

77. Maiese K. Marking the onset of oxidative stress: Biomarkers and novel strategies. Oxid Med Cell Longev 2009; 2:1.

78. Maiese K, Chong ZZ, Li F, Shang YC. Erythropoietin: Elucidating new cellular targets that broaden therapeutic strategies. Prog Neurobiol 2008; 85:194-213.

79. Maiese K, Chong ZZ, Shang YC. Raves and risks for erythropoietin. Cytokine Growth Factor Rev 2008; 19:145-55.

80. Chong ZZ, Kang JQ, Maiese K. Erythropoietin is a novel vascular protectant through activation of Akt1 and mitochondrial modulation of cysteine proteases. Circulation 2002; 106:2973-9.

81. Chong ZZ, Maiese K. Erythropoietin involves the phosphatidylinositol 3-kinase pathway, 14-3-3 protein and FOXO3a nuclear trafficking to preserve endothelial cell integrity. $\mathrm{Br} \mathrm{J}$ Pharmacol 2007; 150:839-50.

82. Mikati MA, Hokayem JA, Sabban ME. Effects of a single dose of erythropoietin on subsequent seizure susceptibility in rats exposed to acute hypoxia at p10. Epilepsia 2007; 48:175-81.

83. Moon C, Krawczyk M, Paik D, Coleman T, Brines M, Juhaszova M, et al. Erythropoietin, modified to not stimulate red blood cell production, retains its cardioprotective properties. J Pharmacol Exp Ther 2006; 316:999-1005.

84. Um M, Gross AW, Lodish HF. A "classical” homodimeric erythropoietin receptor is essential for the antiapoptotic effects of erythropoietin on differentiated neuroblastoma SHSY5Y and pheochromocytoma PC-12 cells. Cell Signal 2007; 19:634-45.

85. Arcasoy MO. The non-haematopoietic biological effects of erythropoietin. Br J Haematol 2008; 141:14-31.

86. Schumann C, Triantafilou K, Krueger S, Hombach V, Triantafilou M, Becher G, et al. Detection of erythropoietin in exhaled breath condensate of nonhypoxic subjects using a multiplex bead array. Mediators Inflamm 2006; 2006:18061.
87. Kaindl AM, Sifringer M, Koppelstaetter A, Genz K, Loeber R, Boerner C, et al. Erythropoietin protects the developing brain from hyperoxia-induced cell death and proteome changes. Ann Neurol 2008; 64:523-34.

88. Yis U, Kurul SH, Kumral A, Tugyan K, Cilaker S, Yilmaz O, et al. Effect of erythropoietin on oxygeninduced brain injury in the newborn rat. Neurosci Lett 2008; 448:245-9.

89. He Z, Huang L, Wu Y, Wang J, Wang H, Guo L. $\mathrm{DDPH}$ : improving cognitive deficits beyond its alpha1-adrenoceptor antagonism in chronic cerebral hypoperfused rats. Eur J Pharmacol 2008; 588:17888 .

90. Berkingali N, Warnecke A, Gomes P, Paasche G, Tack J, Lenarz T, et al. Neurite outgrowth on cultured spiral ganglion neurons induced by erythropoietin. Hear Res 2008; 243:121-6.

91. Shah RC, Wilson RS, Tang Y, Dong X, Murray A, Bennett DA. Relation of hemoglobin to level of $\operatorname{cog}$ nitive function in older persons. Neuroepidemiology 2009; 32:40-6.

92. Bierer R, Peceny MC, Hartenberger CH, Ohls RK. Erythropoietin concentrations and neurodevelopmental outcome in preterm infants. Pediatrics 2006; 118:635-40.

93. Pillai A, Dhandapani KM, Pillai BA, Terry AV Jr, Mahadik SP. Erythropoietin prevents haloperido treatment-induced neuronal apoptosis through regulation of BDNF. Neuropsychopharmacology 2008; 33:1942-51.

94. Assaraf MI, Diaz Z, Liberman A, Miller WH Jr, Arvanitakis Z, Li Y, et al. Brain erythropoietin receptor expression in Alzheimer disease and mild cognitive impairment. J Neuropathol Exp Neurol 2007; 66:389-98.

95. Palazzuoli A, Silverberg D, Iovine F, Capobianco S, Giannotti G, Calabro A, et al. Erythropoietin improves anemia exercise tolerance and renal function and reduces B-typenatriuretic peptide and hospitalization in patients with heart failure and anemia. Am Heart J 2006; 152:1096-9.

96. Gleissner CA, Klingenberg R, Staritz P, Koch A, Ehlermann P, Wiggenhauser A, et al. Role of erythropoietin in anemia after heart transplantation. Int J Cardiol 2006; 112:341-7.

97. Mocini D, Leone T, Tubaro M, Santini M, Penco M. Structure, production and function of erythropoietin: implications for therapeutical use in cardiovascular disease. Curr Med Chem 2007; 14:2278-87.

98. Digicaylioglu M, Garden G, Timberlake S, Fletcher L, Lipton SA. Acute neuroprotective synergy of erythropoietin and insulin-like growth factor I. Proc Natl Acad Sci USA 2004; 101:9855-60

99. Genc S, Koroglu TF, Genc K. Erythropoietin as a novel neuroprotectant. Restor Neurol Neurosci 2004; 22:105-19.

100. Anagnostou A, Liu Z, Steiner M, Chin K, Lee ES, Kessimian N, et al. Erythropoietin receptor mRNA expression in human endothelial cells. Proc Nat Acad Sci USA 1994; 91:3974-8.

101. Ogilvie M, Yu X, Nicolas-Metral V, Pulido SM, Liu C, Ruegg UT, et al. Erythropoietin stimulates proliferation and interferes with differentiation of myoblasts. J Biol Chem 2000; 275:39754-61.

102. Fenjves ES, Ochoa MS, Cabrera O, Mendez AJ, Kenyon NS, Inverardi L, et al. Human, nonhuman primate and rat pancreatic islets express erythropoietin receptors. Transplantation 2003; 75:1356-60.

103. Chong ZZ, Kang JQ, Maiese K. Erythropoietin cytoprotection in vascular and neuronal cells. Curr Drug Targets Cardiovasc Haematol Disord 2003; 3:141-54.

104. Yamaji R, Okada T, Moriya M, Naito M, Tsuruo T, Miyatake K, et al. Brain capillary endothelial cells express two forms of erythropoietin receptor mRNA. Eur J Biochem 1996; 239:494-500.
105. Maiese K, Chong Z, Li F. Reducing oxidative stress and enhancing neurovascular longevity during diabetes mellitus. In: Neurovascular Medicine: Pursuing Cellular Longevity for Healthy Aging Maiese K, Ed, Oxford University Press: New York, NY 2009; 540-64

106. Chong ZZ, Kang JQ, Maiese K. Hematopoietic factor erythropoietin fosters neuroprotection through novel signal transduction cascades. J Cereb Blood Flow Metab 2002; 22:503-14.

107. Obara N, Imagawa S, Nakano Y, Suzuki N, Yamamoto M, Nagasawa T. Suppression of erythropoietin gene expression by cadmium depends on inhibition of HIF-1, not stimulation of GATA-2 Arch Toxicol 2003; 77:267-73

108. Li CL, Jiang J, Fan YQ, Fu GS, Wang JA, Fan WM. Knockout of the tumor necrosis factor a receptor 1 gene can upregulate erythropoietin receptor during myocardial ischemiareperfusion injury in mice. Chin Med J (Engl) 2009; 122:566-70.

109. Nagai A, Nakagawa E, Choi HB, Hatori K, Kobayashi S, Kim SU. Erythropoietin and erythropoietin receptors in human CNS neurons, astrocytes, microglia and oligodendrocytes grown in culture. J Neuropathol Exp Neurol 2001; 60:386-92.

110. Pregi N, Wenker S, Vittori D, Leiros CP, Nesse A. TNFalpha-induced apoptosis is prevented by erythropoietin treatment on SH-SY5Y cells. Exp Cell Res 2009; 315:419-31.

111. Maiese K, Chong ZZ, Shang YC, Hou J. A "FOXO" in sight: targeting Foxo proteins from conception to cancer. Med Res Rev 2009; 29:395-418.

112. Weigel D, Jurgens G, Kuttner F, Seifert E, Jackle $\mathrm{H}$. The homeotic gene fork head encodes a nuclear protein and is expressed in the terminal regions of the Drosophila embryo. Cell 1989; 57:645-58.

113. Maiese K, Chong ZZ, Shang YC. "Sly as a FOXO": New paths with Forkhead signaling in the brain. Curr Neurovasc Res 2007; 4:295-302.

114. Kaestner KH, Knochel W, Martinez DE. Unified nomenclature for the winged helix/forkhead transcription factors. Genes Dev 2000; 14:142-6.

115. Maiese K, Chong ZZ, Shang YC. OutFOXOing disease and disability: the therapeutic potential of targeting FoxO proteins. Trends Mol Med 2008; 14:219-27.

116. Maiese K, Chong ZZ, Shang YC, Hou J. FoxO proteins: cunning concepts and considerations for the cardiovascular system. Clin Sci (Lond) 2009 116:191-203.

117. Maiese K, Li F, Chong ZZ. Erythropoietin and cancer. JAMA 2005; 293:1858-9.

118. Bloomer R, Fisher-Wellman K. Systemic oxidative stress is increased to a greater degree in young, obese women following consumption of a high fat meal. Oxid Med Cell Longev 2009; 2:19-25.

119. Fisher-Wellman K, Bell H, Bloomer R. Oxidative stress and antioxidant defense mechanisms linked to exercise during cardiopulmonary and metabolic disorders. Oxid Med Cell Longev 2009; 2:43-51.

120. Castrillon DH, Miao L, Kollipara R, Horner JW, DePinho RA. Suppression of ovarian follicle activation in mice by the transcription factor Foxo3a. Science 2003; 301:215-8

121. Furuyama T, Nakazawa T, Nakano I, Mori N. Identification of the differential distribution patterns of mRNAs and consensus binding sequences for mouse DAF-16 homologues. Biochem J 2000; 349:629-34.

122. Furuyama T, Yamashita H, Kitayama K, Higami Y, Shimokawa I, Mori N. Effects of aging and caloric restriction on the gene expression of Foxol, 3 and 4 (FKHR, FKHRL1 and AFX) in the rat skeletal muscles. Microsc Res Tech 2002; 59:331-4.

123. Hoekman MF, Jacobs FM, Smidt MP, Burbach JP. Spatial and temporal expression of FoxO transcription factors in the developing and adult murine brain Gene Expr Patterns 2006; 6:134-40. 
124. Lappas M, Lim R, Riley C, Rice GE, Permezel M. Localisation and expression of FoxO1 proteins in human gestational tissues. Placenta 2009; 30:25662.

125. Maiese K, Chong Z, Hou J, Shang Y. The "O" Class: Crafting clinical care with FoxO transcription factors. In: Forkhead Transcription Factors: Vital Elements in Biology and Medicine Maiese K, Ed., Landes Bioscience, Austin, TX 2009; 665.

126. Maiese K, Chong ZZ, Shang YC, Hou J. Clever cancer strategies with FoxO transcription factors. Cell Cycle 2008; 7:3829-39.

127. Modur V, Nagarajan R, Evers BM, Milbrandt J. FOXO proteins regulate tumor necrosis factor-related apoptosis inducing ligand expression. Implications for PTEN mutation in prostate cancer. J Biol Chem 2002; 277:47928-37.

128. Matsuzaki H, Daitoku H, Hatta M, Tanaka K, Fukamizu A. Insulin-induced phosphorylation of FKHR (Foxo1) targets to proteasomal degradation. Proc Natl Acad Sci USA 2003; 100:11285-90.

129. Plas DR, Thompson CB. Akt activation promotes degradation of tuberin and $\mathrm{FOXO} 3$ a via the proteasome. J Biol Chem 2003; 278:12361-6.

130. Jagani Z, Singh A, Khosravi-Far R. FoxO tumor suppressors and BCR-ABL-induced leukemia: a matter of evasion of apoptosis. Biochim Biophys Acta 2008; 1785:63-84.

131. van der Horst A, Burgering BM. Stressing the role of FoxO proteins in lifespan and disease. Nat Rev Mol Cell Biol 2007; 8:440-50.

132. Song M, Park JE, Park SG, Lee do H, Choi HK, Park BC, et al. NSC-87877, inhibitor of SHP-1/2 PTPs, inhibits dual-specificity phosphatase 26 (DUSP26). Biochem Biophys Res Commun 2009; 381:491-5.

133. Chong ZZ, Li F, Maiese K. Activating Akt and the brain's resources to drive cellular survival and prevent inflammatory injury. Histol Histopathol 2005; 20:299-315.

134. Gayer CP, Chaturvedi LS, Wang S, Craig DH, Flanigan T, Basson MD. Strain-induced proliferation requires the phosphatidylinositol 3-kinase/AKT/ glycogen synthase kinase pathway. J Biol Chem 2009; 284:2001-11.

135. An J, Zhang C, Polavarapu R, Zhang X, Yepes M. Tissue-type plasminogen activator and the lowdensity lipoprotein receptor-related protein induce Akt phosphorylation in the ischemic brain. Blood 2008; 112:2787-94.

136. Slaets H, Dumont D, Vanderlocht J, Noben JP, Leprince P, Robben J, et al. Leukemia inhibitory factor induces an antiapoptotic response in oligodendrocytes through Aktphosphorylation and upregulation of 14-3-3. Proteomics 2008; 8:1237-47.

137. Williams R, Dhillon NK, Hegde ST, Yao H, Peng F, Callen S, et al. Proinflammatory cytokines and HIV-1 synergistically enhance CXCL10 expression in human astrocytes. Glia 2009; 57:734-43.

138. Rodriguez-Blanco J, Martin V, Herrera F, GarciaSantos G, Antolin I, Rodriguez C. Intracellular signaling pathways involved in post-mitotic dopaminergic PC12 cell death induced by 6-hydroxydopamine. J Neurochem 2008; 107:127-40.

139. Anitha M, Gondha C, Sutliff R, Parsadanian A, Mwangi S, Sitaraman SV, et al. GDNF rescues hyperglycemia-induced diabetic enteric neuropathy through activation of the PI3K/Akt pathway. J Clin Invest 2006; 116:344-56.

140. Burgos-Ramos E, Martos-Moreno GA, Lopez MG, Herranz R, Aguado-Llera D, Egea J, et al. The $\mathrm{N}$-terminal tripeptide of insulin-like growth factor-I protects against beta-amyloidinduced somatostatin depletion by calcium and glycogen synthase kinase 3 beta modulation. J Neurochem 2009; 109:360-70.
141. Burgos-Ramos E, Puebla-Jimenez L, Arilla-Ferreiro E. Minocycline provides protection against betaamyloid(25-35)-induced alterations of the somatostatin signaling pathway in the rat temporal cortex. Neuroscience 2008; 154:1458-66.

142. Burgos-Ramos E, Puebla-Jimenez L, Arilla-Ferreiro E. Minocycline prevents Abeta(25-35)-induced reduction of somatostatin and neprilysin content in rat temporal cortex. Life Sci 2009; 84:205-10.

143. Chong ZZ, Li F, Maiese K. Erythropoietin requires NFkappaB and its nuclear translocation to preven early and late apoptotic neuronal injury during betaamyloid toxicity. Curr Neurovasc Res 2005; 2:38799.

144. Campos-Esparza MR, Sanchez-Gomez MV, Matute C. Molecular mechanisms of neuroprotection by two natural antioxidant polyphenols. Cell Calcium 2009; 45:358-68.

145. Kim KH, Oudit GY, Backx PH. Erythropoietin protects against doxorubicin-induced cardiomyopathy via a phosphatidylinositol 3-kinase-dependent pathway. J Pharmacol Exp Ther 2008; 324:160-9.

146. Tajes M, Yeste-Velasco M, Zhu X, Chou SP, Smith MA, Pallas M, et al. Activation of Akt by lithium: Pro-survival pathways in aging. Mech Ageing Dev 2009.

147. Maiese K, Chong ZZ, Li F. Driving cellular plasticity and survival through the signal transduction pathways of metabotropic glutamate receptors. Curr Neurovasc Res 2005; 2:425-46.

148. Salvesen GS, Riedl SJ. Caspase mechanisms. Adv Exp Med Biol 2008; 615:13-23.

149. Chong ZZ, Li F, Maiese K. Group I Metabotropic Receptor Neuroprotection Requires Akt and Its Substrates that Govern FOXO3a, Bim and betaCatenin During Oxidative Stress. Curr Neurovasc Res 2006; 3:107-17.

150. Chong ZZ, Lin SH, Maiese K. The NAD+ precursor nicotinamide governs neuronal survival during oxidative stress through protein kinase B coupled to FOXO3a and mitochondrial membrane potential. J Cereb Blood Flow Metab 2004; 24:728-43.

151. Obexer P, Geiger K, Ambros PF, Meister B, Ausserlechner MJ. FKHRL1-mediated expression of Noxa and Bim induces apoptosis via the mitochondria in neuroblastoma cells. Cell Death Differ 2007; 14:534-47.

152. Gomez-Gutierrez JG, Souza V, Hao HY, Montes de Oca-Luna R, Dong YB, Zhou HS, et al. Adenovirusmediated gene transfer of FKHRL1 triple mutan efficiently induces apoptosis in melanoma cells. Cancer biology \& therapy 2006; 5:875-83.

153. Maiese K, Chong ZZ, Shang YC. Mechanistic insights into diabetes mellitus and oxidative stress. Curr Med Chem 2007; 14:1729-38.

154. Maiese K, Morhan SD, Chong ZZ. Oxidative stress biology and cell injury during type 1 and type 2 diabetes mellitus. Curr Neurovasc Res 2007; 4:63-71.

155. Hao J, Shen W, Tian C, Liu Z, Ren J, Luo C, et al. Mitochondrial nutrients improve immune dysfunction in the type 2 diabetic Goto-Kakizaki rats. J Cell Mol Med 2009; 13:701-11.

156. Kuhad A, Bishnoi M, Tiwari V, Chopra K. Suppression of NFkappabeta signaling pathway by tocotrienol can prevent diabetes associated cognitive deficits. Pharmacol Biochem Behav 2009; 92:251-9.

157. Wu SY, Wang GF, Liu ZQ, Rao JJ, Lu L, Xu W, et al. Effect of geniposide, a hypoglycemic glucoside, on hepatic regulating enzymes in diabetic mice induced by a high-fat diet and streptozotocin. Acta Pharmacol Sin 2009; 30:202-8.

158. Guarnieri G, Zanetti M, Vinci P, Cattin MR, Barazzoni R. Insulin resistance in chronic uremia. J Ren Nutr 2009; 19:20-4.
159. Gossai D, Lau-Cam CA. The effects of taurine, taurine homologs and hypotaurine on cell and membrane antioxidative system alterations caused by type 2 diabetes in rat erythrocytes. Adv Exp Med Biol 2009; 643:359-68.

160. Maiese K. Diabetic stress: new triumphs and challenges to maintain vascular longevity. Expert Rev Cardiovasc Ther 2008; 6:281-4.

161. Donahoe SM, Stewart GC, McCabe CH, Mohanavelu S, Murphy SA, Cannon CP, et al. Diabetes and mortality following acute coronary syndromes. JAMA 2007; 298:765-75.

162. Silverberg DS, Wexler D, Iaina A, Schwartz D. The interaction between heart failure and other heart diseases, renal failure and anemia. Semin Nephrol 2006 ; 26:296-306

163. Chong ZZ, Shang YC, Maiese K. Vascular injury during elevated glucose can be mitigated by erythropoietin and Wnt signaling. Curr Neurovasc Res 2007; 4:194-204.

164. Mason-Garcia M, Beckman BS, Brookins JW, Powell JS, Lanham W, Blaisdell S, et al. Development of a new radioimmunoassay for erythropoietin using recombinant erythropoietin. Kidney Int 1990; 38:969-75.

165. Namiuchi S, Kagaya Y, Ohta J, Shiba N, Sugi M, Oikawa M, et al. High serum erythropoietin level is associated with smaller infarct size in patients with acute myocardial infarction who undergo successful primary percutaneous coronary intervention. J Am Coll Cardiol 2005; 45:1406-12.

166. Chattopadhyay M, Walter C, Mata M, Fink DJ. Neuroprotective effect of herpes simplex virus-mediated gene transfer of erythropoietin in hyperglycemic dorsal root ganglion neurons. Brain 2009; 132:87988.

167. Avasarala JR, Konduru SS. Recombinant erythropoietin downregulates IL- 6 and CXCR 4 genes in TNFalpha-treated primary cultures of human microvascular endothelial cells: implications for multiple sclerosis. J Mol Neurosci 2005; 25:183-9.

168. Miki T, Miura T, Yano T, Takahashi A, Sakamoto J, Tanno M, et al. Alteration in erythropoietin-induced cardioprotective signaling by postinfarct ventricular remodeling. J Pharmacol Exp Ther 2006; 317:6875.

169. Espada J, Calvo MB, Diaz-Prado S, Medina V. Wnt signalling and cancer stem cells. Clin Transl Oncol 2009; 11:411-27.

170. Wilusz M, Majka M. Role of the Wnt/beta-catenin network in regulating hematopoiesis. Arch Immunol Ther Exp (Warsz) 2008; 56:257-66.

171. Maiese K, Li F, Chong ZZ, Shang YC. The Wnt signaling pathway: Aging gracefully as a protectionist? Pharmacol Ther 2008; 118:58-81.

172. Kikuchi A, Yamamoto H, Sato A. Selective activation mechanisms of Wnt signaling pathways. Trends Cell Biol 2009; 19:119-29.

173. Grant SF, Thorleifsson G, Reynisdottir I, Benediktsson R, Manolescu A, Sainz J, et al. Variant of transcription factor 7-like 2 (TCF7L2) gene confers risk of type 2 diabetes. Nat Genet 2006; 38:3203.

174. Lehman DM, Hunt KJ, Leach RJ, Hamlington J, Arya $\mathrm{R}$, Abboud HE, et al. Haplotypes of Transcription Factor 7-Like 2 (TCF7L2) Gene and Its Upstream Region Are Associated With Type 2 Diabetes and Age of Onset in Mexican Americans. Diabetes 2007; 56:389-93.

175. Scott LJ, Bonnycastle LL, Willer CJ, Sprau AG, Jackson AU, Narisu N, et al. Association of transcription factor 7-like 2 (TCF7L2) variants with type 2 diabetes in a Finnish sample. Diabetes 2006 ; 55:2649-53 
176. Guo YF, Xiong DH, Shen H, Zhao LJ, Xiao P, Guo $\mathrm{Y}$, et al. Polymorphisms of the lowdensity lipoprotein receptor-related protein 5 (LRP5) gene are associated with obesity phenotypes in a large family-based association study. J Med Genet 2006; 43:798-803.

177. Wright WS, Longo KA, Dolinsky VW, Gerin I, Kang $\mathrm{S}$, Bennett CN, et al. Wnt10b Inhibits Obesity in ob/ ob and Agouti Mice. Diabetes 2007; 56:295-303.

178. Lin CL, Wang JY, Huang YT, Kuo YH, Surendran $\mathrm{K}$, Wang FS. Wnt/beta-catenin signaling modulates survival of high glucose-stressed mesangial cells. J Am Soc Nephrol 2006; 17:2812-20.

179. Kim JR, Jung HS, Bae SW, Kim JH, Park BL, Choi $\mathrm{YH}$, et al. Polymorphisms in FOXO gene family and association analysis with BMI. Obesity (Silver Spring, Md) 2006; 14:188-93.

180. Marchetti V, Menghini R, Rizza S, Vivanti A, Feccia T, Lauro D, et al. Benfotiamine counteracts glucose toxicity effects on endothelial progenitor cell differentiation via Akt/FoxO signaling. Diabetes 2006; 55:2231-7.

181. Fallarino F, Bianchi R, Orabona C, Vacca C, Belladonna ML, Fioretti MC, et al. CTLA-4-Ig activates forkhead transcription factors and protects dendritic cells from oxidative stress in nonobese diabetic mice. J Exp Med 2004; 200:1051-62.

182. Nakae J, Cao Y, Oki M, Orba Y, Sawa H, Kiyonari $\mathrm{H}$, et al. Forkhead transcription factor FoxO1 in adipose tissue regulates energy storage and expenditure. Diabetes 2008; 57:563-76.

183. Puig O, Tjian R. Transcriptional feedback control of insulin receptor by dFOXO/FOXO1. Genes Dev 2005; 19:2435-46.

184. Kamagate A, Dong HH. Foxol integrates insulin signaling to VLDL production. Cell Cycle 2008; 7:3162-70.

185. Ni YG, Wang N, Cao DJ, Sachan N, Morris DJ, Gerard RD, et al. FoxO transcription factors activate Akt and attenuate insulin signaling in heart by inhibiting protein phosphatases. Proc Natl Acad Sci USA 2007; 104:20517-22.

186. Kamei Y, Miura S, Suzuki M, Kai Y, Mizukami J, Taniguchi T, et al. Skeletal muscle FOXO1 (FKHR) transgenic mice have less skeletal muscle mass, downregulated Type I (slow twitch/red muscle) fiber genes, and impaired glycemic control. J Biol Chem 2004; 279:41114-23.

187. Liu CM, Yang Z, Liu CW, Wang R, Tien P, Dale R, et al. Effect of RNA oligonucleotide targeting Foxo-1 on muscle growth in normal and cancer cachexia mice. Cancer Gene Ther 2007; 14:945-52.

188. Sandri M, Lin J, Handschin C, Yang W, Arany $\mathrm{ZP}$, Lecker $\mathrm{SH}$, et al. PGC-1alpha protects skeletal muscle from atrophy by suppressing FoxO3 action and atrophy-specific gene transcription. Proc Nat Acad Sci USA 2006; 103:16260-5.

189. Balan V, Miller GS, Kaplun L, Balan K, Chong ZZ, Li F, et al. Life span extension and neuronal cell protection by Drosophila nicotinamidase. J Biol Chem 2008; 283:27810-9

190. Chong ZZ, Maiese K. Enhanced Tolerance against Early and Late Apoptotic Oxidative Stress in Mammalian Neurons through Nicotinamidase and Sirtuin Mediated Pathways. Curr Neurovasc Res 2008; 5:159-70

191. Ma R, Xiong N, Huang C, Tang Q, Hu B, Xiang $\mathrm{J}$, et al. Erythropoietin protects $\mathrm{PC} 12$ cells from beta-amyloid(25-35)-induced apoptosis via PI3K/ Akt signaling pathway. Neuropharmacology 2009; 56:1027-34.

192. Sun ZK, Yang HQ, Pan J, Zhen H, Wang ZQ, Chen $S D$, et al. Protective effects of erythropoietin on tau phosphorylation induced by beta-amyloid. J Neurosci Res 2008; 86:3018-27.

193. Liu R, Suzuki A, Guo Z, Mizuno Y, Urabe T. Intrinsic and extrinsic erythropoietin enhances neuroprotection against ischemia and reperfusion injury in vitro. J Neurochem 2006; 96:1101-10.
194. Meloni BP, Tilbrook PA, Boulos S, Arthur PG, Knuckey NW. Erythropoietin preconditioning in neuronal cultures: signaling, protection from in vitro ischemia, and proteomic analysis. J Neurosci Res 2006; 83:584-93.

195. Wei L, Han BH, Li Y, Keogh CL, Holtzman DM, Yu SP. Cell death mechanism and protective effect of erythropoietin after focal ischemia in the whiskerbarrel cortex of neonatal rats. J Pharmacol Exp Ther 2006; 317:109-16.

196. Yu YP, Xu QQ, Zhang Q, Zhang WP, Zhang LH, Wei EQ. Intranasal recombinant human erythropoietin protects rats against focal cerebral ischemia. Neurosci Lett 2005; 387:5-10.

197. Montero M, Poulsen FR, Noraberg J, Kirkeby A, van Beek J, Leist M, et al. Comparison of neuroprotective effects of erythropoietin (EPO) and carbamylerythropoietin (CEPO) against ischemia-like oxygen-glucose deprivation (OGD) and NMDA excitotoxicity in mouse hippocampal slice cultures. Exp Neurol 2007; 204:106-17.

198. Yamasaki M, Mishima HK, Yamashita H, Kashiwagi K, Murata K, Minamoto A, et al. Neuroprotective effects of erythropoietin on glutamate and nitric oxide toxicity in primary cultured retinal ganglion cells. Brain Res 2005; 1050:15-26.

199. Yoo JY, Won YJ, Lee JH, Kim JU, Sung IY, Hwang SJ, et al. Neuroprotective effects of erythropoietin posttreatment against kainate-induced excitotoxic ity in mixed spinal cultures. J Neurosci Res 2009; 87:150-63

200. Bienvenu AL, Ferrandiz J, Kaiser K, Latour C, Picot S. Artesunate-erythropoietin combination for murine cerebral malaria treatment. Acta Trop 2008; 106:104-8.

201. Casals-Pascual C, Idro R, Picot S, Roberts DJ, Newton CR. Can erythropoietin be used to preven brain damage in cerebral malaria? Trends Parasito 2009; 25:30-6.

202. Kaiser K, Texier A, Ferrandiz J, Buguet A, Meiller A, Latour C, et al. Recombinant human erythropoietin prevents the death of mice during cerebral malaria. Infect Dis 2006; 193:987-95.

203. Aoshiba K, Onizawa S, Tsuji T, Nagai A. Therapeutic effects of erythropoietin in murine models of endotoxin shock. Crit Care Med 2009; 37:889-98.

204. Wagner F, Baumgart K, Simkova V, Georgieff M, Radermacher P, Calzia E. Year in review 2007: Critical Care-shock. Crit Care 2008; 12:227.

205. Chen HH, Tarng DC, Lee KF, Wu CY, Chen YC. Epoetin alfa and darbepoetin alfa: effects on ventricular hypertrophy in patients with chronic kidney disease. J Nephrol 2008; 21:543-9.

206. Mao W, Iwai C, Liu J, Sheu SS, Fu M, Liang CS. Darbepoetin alfa exerts a cardioprotective effect in autoimmune cardiomyopathy via reduction of ER stress and activation of the PI3K/Akt and STAT3 pathways. J Mol Cell Cardiol 2008; 45:250-60.

207. Tascilar O, Cakmak GK, Tekin IO, Emre AU, Ucan $\mathrm{BH}, \mathrm{Bahadir} \mathrm{B}$, et al. Protective effects of erythropoietin against acute lung injury in a rat model of acute necrotizing pancreatitis. World J Gastroenterol 2007; 13:6172-82.

208. Wu H, Dong G, Liu H, Xu B, Li D, Jing H. Erythropoietin attenuates ischemiareperfusion induced lung injury by inhibiting tumor necrosis factor-alpha and matrix metalloproteinase- 9 expression. Eur J Pharmacol 2009; 602:406-12.

209. Chen J, Connor KM, Aderman CM, Willett KL, Aspegren OP, Smith LE. Suppression of retinal neovascularization by erythropoietin siRNA in a mouse model of proliferative retinopathy. Invest Ophthalmol Vis Sci 2009; 50:1329-35.

210. Wang ZY, Shen LJ, Tu L, Hu DN, Liu GY, Zhou ZL, et al. Erythropoietin protects retinal pigment epithelial cells from oxidative damage. Free Radic Biol Med 2009; 46:1032-41.
211. Zhong Y, Yao H, Deng L, Cheng Y, Zhou X. Promotion of neurite outgrowth and protective effect of erythropoietin on the retinal neurons of rats. Graefes Arch Clin Exp Ophthalmol 2007; 245:185967.

212. Zhong YS, Liu XH, Cheng Y, Min YJ. Erythropoietin with retrobulbar administration protects retinal ganglion cells from acute elevated intraocular pressure in rats. J Ocul Pharmacol Ther 2008; 24:453-9.

213. Tsai JC, Song BJ, Wu L, Forbes M. Erythropoietin: a candidate neuroprotective agent in the treatment of glaucoma. J Glaucoma 2007; 16:567-71.

214. King VR, Averill SA, Hewazy D, Priestley JV, Torup L, Michael-Titus AT. Erythropoietin and carbamylated erythropoietin are neuroprotective following spinal cord hemisection in the rat. Eur J Neurosci 2007; 26:90-100.

215. Okutan O, Solaroglu I, Beskonakli E, Taskin Y. Recombinant human erythropoietin decreases myeloperoxidase and caspase- 3 activity and improves early functional results after spinal cord injury in rats. J Clin Neurosci 2007; 14:364-8.

216. Verdonck O, Lahrech H, Francony G, Carle O, Farion R, Van de Looij Y, et al. Erythropoietin protects from post-traumatic edema in the rat brain. J Cereb Blood Flow Metab 2007; 27:1369-76.

217. Cherian L, Goodman JC, Robertson C. Neuroprotection with erythropoietin administration following controlled cortical impact injury in rats. J Pharmacol Exp Ther 2007; 322:789-94.

218. Chu K, Jung KH, Lee ST, Kim JH, Kang KM, Kim $\mathrm{HK}$, et al. Erythropoietin reduces epileptogenic processes following status epilepticus. Epilepsia 2008; 49:1723-32.

219. Nadam J, Navarro F, Sanchez P, Moulin C, Georges B, Laglaine A, et al. Neuroprotective effects of erythropoietin in the rat hippocampus after pilocarpineinduced status epilepticus. Neurobiol Dis 2007; 25:412-26

220. Ferri C, Giuggioli D, Sebastiani M, Colaci M. Treatment of severe scleroderma skin ulcers with recombinant human erythropoietin. Clin Exp Dermatol 2007; 32:287-90.

221. Cuzzocrea S, Mazzon E, di Paola R, Genovese T, Patel NS, Britti D, et al. Erythropoietin reduces the degree of arthritis caused by type II collagen in the mouse. Arthritis Rheum 2005; 52:940-50.

222. Wu Y, Shang Y, Sun S, Liang H, Liu R. Erythropoietin prevents PC12 cells from 1-methyl-4-phenylpyridinium ion-induced apoptosis via the Akt/GSK-3beta/ caspase-3 mediated signaling pathway. Apoptosis 2007; 12:1365-75.

223. Li F, Chong ZZ, Maiese K. Erythropoietin on a Tightrope: Balancing Neuronal and Vascular Protection between Intrinsic and Extrinsic Pathways. Neurosignals 2004; 13:265-89.

224. Contaldo C, Meier C, Elsherbiny A, Harder Y, Trentz O, Menger MD, et al. Human recombinant erythropoietin protects the striated muscle microcirculation of the dorsal skinfold from postischemic injury in mice. Am J Physiol Heart Circ Physiol 2007; 293:274-83.

225. Vairano M, Dello Russo C, Pozzoli G, Battaglia A, Scambia G, Tringali G, et al. Erythropoietin exerts anti-apoptotic effects on rat microglial cells in vitro. Eur J Neurosci 2002; 16:584-92.

226. Nakamura T, Sakamoto K. Forkhead transcription factor FOXO subfamily is essential for reactive oxygen species-induced apoptosis. Mol Cell Endocrinol 2007; 281:47-55.

227. Barthelemy C, Henderson CE, Pettmann B. Foxo3a induces motoneuron death through the Fas pathway in cooperation with JNK. BMC Neurosci 2004; $5: 48$.

228. You H, Yamamoto K, Mak TW. Regulation of transactivation-independent proapoptotic activity of p53 by FOXO3a. Proc Natl Acad Sci USA 2006; 103:9051-6. 
229. Won CK, Ji HH, Koh PO. Estradiol prevents the focal cerebral ischemic injury-induced decrease of forkhead transcription factors phosphorylation. Neurosci Lett 2006; 398:39-43.

230. Caporali A, Sala-Newby GB, Meloni M, Graiani G, Pani E, Cristofaro B, et al. Identification of the prosurvival activity of nerve growth factor on cardiac myocytes. Cell Death Differ 2008; 15:299-311.

231. Slotkin TA, Seidler FJ. Protein kinase C is a target for diverse developmental neurotoxicants: transcriptional responses to chlorpyrifos, diazinon, dieldrin and divalent nickel in PC12 cells. Brain Res 2009; 1263:23-32.

232. Slotkin TA, Seidler FJ, Fumagalli F. Targeting of neurotrophic factors, their receptors, and signaling pathways in the developmental neurotoxicity of organophosphates in vivo and in vitro. Brain Res Bull 2008; 76:424-38.

233. Erol A. Unraveling the Molecular Mechanisms Behind the Metabolic Basis of Sporadic Alzheimer's Disease. J Alzheimers Dis 2009.

234. Lu J, Wu DM, Zheng YL, Sun DX, Hu B, Shan $\mathrm{Q}$, et al. Trace amounts of copper exacerbate beta amyloid-induced neurotoxicity in the cholesterol-fed mice through TNF mediated inflammatory pathway. Brain Behav Immun 2009; 23:193-203.

235. Smith WW, Norton DD, Gorospe M, Jiang H, Nemoto S, Holbrook NJ, et al. Phosphorylation of p66Shc and forkhead proteins mediates Abeta toxicity. J Cell Biol 2005; 169:331-9.

236. Mercado-Gomez O, Hernandez-Fonseca K, Villavicencio-Queijeiro A, Massieu L, ChimalMonroy J, Arias C. Inhibition of Wnt and PI3K signaling modulates GSK-3beta activity and induces morphological changes in cortical neurons: role of tau phosphorylation. Neurochem Res 2008; 33:1599609.

237. Hoogeboom D, Essers MA, Polderman PE, Voets E, Smits LM, Burgering BM. Interaction of FOXO with $\{$ beta $\}-C a t e n i n$ Inhibits $\{$ beta $\}-C a t e n i n / T$ Cell Factor Activity. J Biol Chem 2008; 283:9224-30.
238. Tothova Z, Kollipara R, Huntly BJ, Lee BH, Castrillon DH, Cullen DE, et al. FoxOs are critica mediators of hematopoietic stem cell resistance to physiologic oxidative stress. Cell 2007; 128:325-39.

239. Ferrara N, Rinaldi B, Corbi G, Conti V, Stiuso P, Boccuti S, et al. Exercise Training Promotes SIRT1 Activity in Aged Rats. Rejuvenation Res 2008; 11:139-50.

240. Baoutina A, Alexander IE, Rasko JE, Emslie KR. Potential use of gene transfer in athletic performance enhancement. Mol Ther 2007; 15:1751-66.

241. Diamanti-Kandarakis E, Konstantinopoulos PA Papailiou J, Kandarakis SA, Andreopoulos A, Sykiotis GP. Erythropoietin abuse and erythropoietin gene doping: detection strategies in the genomic era. Sports Med 2005; 35:831-40.

242. Segura J, Pascual JA, Gutierrez-Gallego R. Procedure for monitoring recombinant erythropoietin and analogues in doping control. Anal Bioanal Chem 2007; 388:1521-9.

243. Frietsch T, Maurer MH, Vogel J, Gassmann M Kuschinsky W, Waschke KF. Reduced cerebral blood flow but elevated cerebral glucose metabolic rate in erythropoietin overexpressing transgenic mice with excessive erythrocytosis. J Cereb Blood Flow Metab 2007; 27:469-76.

244. Eliopoulos N, Gagnon RF, Francois M, Galipeau J. Erythropoietin delivery by genetically engineered bone marrow stromal cells for correction of anemia in mice with chronic renal failure. J Am Soc Nephro 2006; 17:1576-84.

245. Orive G, De Castro M, Ponce S, Hernandez RM, Gascon AR, Bosch M, et al. Long-term expression of erythropoietin from myoblasts immobilized in biocompatible and neovascularized microcapsules. Mol Ther 2005; 12:283-9.

246. Ponce S, Orive G, Hernandez RM, Gascon AR, Canals JM, Munoz MT, et al. In vivo evaluation of EPO-secreting cells immobilized in differen alginate-PLL microcapsules. J Control Release 2006; $116: 28-34$.
247. Doolittle ND, Peereboom DM, Christoforidis GA Hall WA, Palmieri D, Brock PR, et al. Delivery of chemotherapy and antibodies across the blood-brain barrier and the role of chemoprotection, in primary and metastatic brain tumors: report of the Eleventh Annual Blood-Brain Barrier Consortium meeting. J Neurooncol 2007; 81:81-91.

248. Gonzalez FF, McQuillen P, Mu D, Chang Y, Wendland M, Vexler Z, et al. Erythropoietin enhances long-term neuroprotection and neurogenesis in neonatal stroke. Dev Neurosci 2007; 29:321-30.

249. Li Y, Lu Z, Keogh CL, Yu SP, Wei L. Erythropoietininduced neurovascular protection, angiogenesis and cerebral blood flow restoration after focal ischemia in mice. J Cereb Blood Flow Metab 2007; 27:1043-54.

250. Reinders ME, Rabelink TJ, Briscoe DM. Angiogenesis and endothelial cell repair in renal disease and allograft rejection. J Am Soc Nephrol 2006; 17:93242.

251. Slevin M, Kumar P, Gaffney J, Kumar S, Krupinski J. Can angiogenesis be exploited to improve stroke outcome? Mechanisms and therapeutic potential. Clin Sci 2006; 111:171-83.

252. Zhang SX, Ma JX. Ocular neovascularization: Implication of endogenous angiogenic inhibitors and potential therapy. Prog Retin Eye Res 2007; 26:1-37.

253. Hellwinkel OJ, Rogmann JP, Asong LE, Luebke AM, Eichelberg C, Ahyai S, et al. A comprehensive analysis of transcript signatures of the phosphatidylinositol-3 kinase/protein kinase B signal-transduction pathway in prostate cancer. BJU Int 2008; 101:1454-60.

254. Zethelius B, Berglund L, Sundstrom J, Ingelsson E, Basu S, Larsson A, et al. Use of multiple biomarkers to improve the prediction of death from cardiovascular causes. N Engl J Med 2008; 358:2107-16.

255. Hannenhalli S, Putt ME, Gilmore JM, Wang J, Parmacek MS, Epstein JA, et al. Transcriptional genomics associates FOX transcription factors with human heart failure. Circulation 2006; 114:126976. 


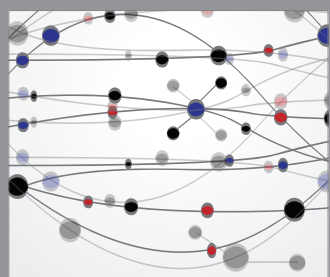

The Scientific World Journal
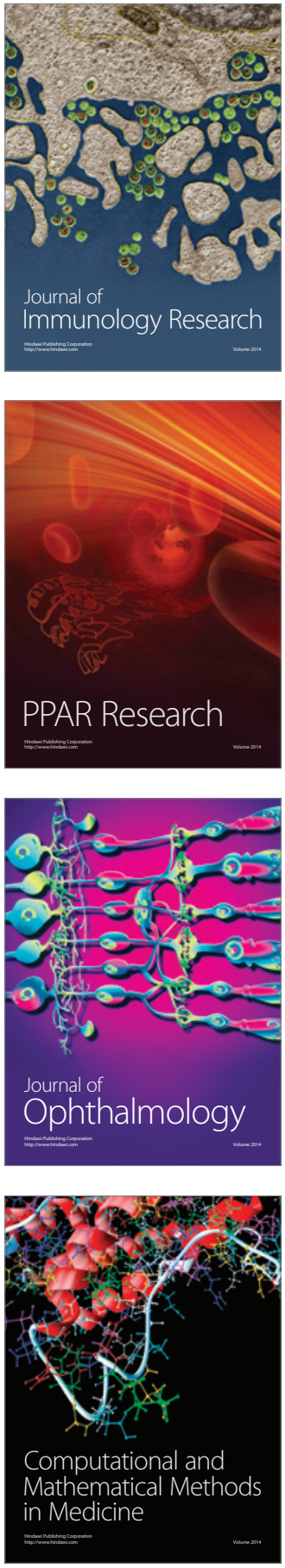

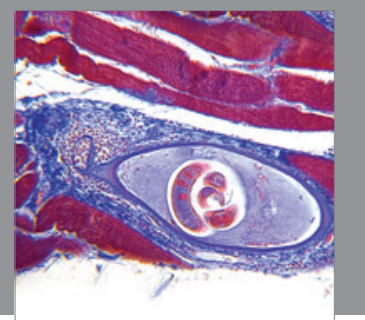

Gastroenterology

Research and Practice
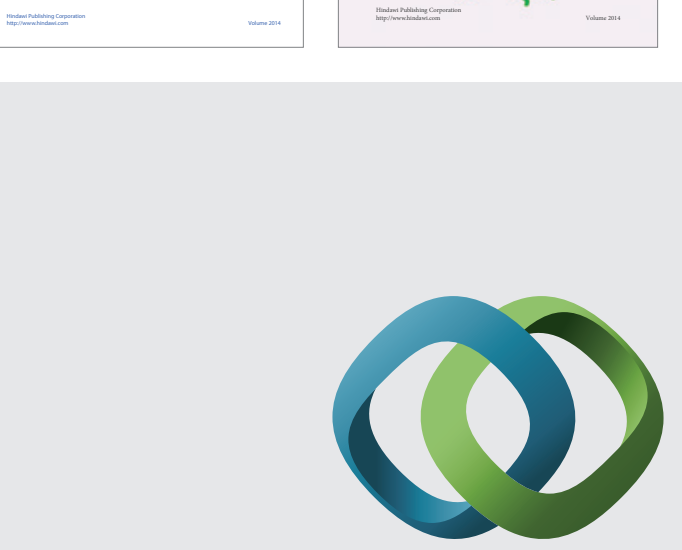

\section{Hindawi}

Submit your manuscripts at

http://www.hindawi.com
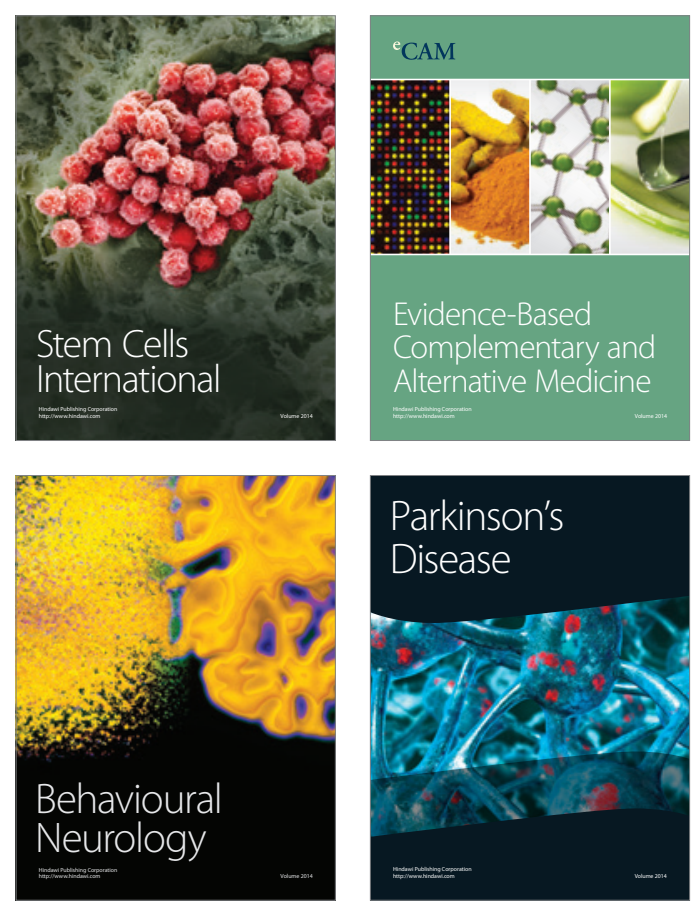

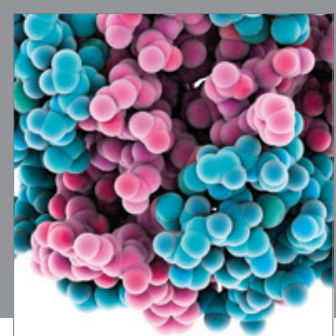

Journal of
Diabetes Research

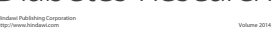

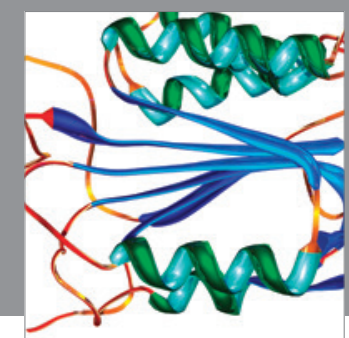

Disease Markers
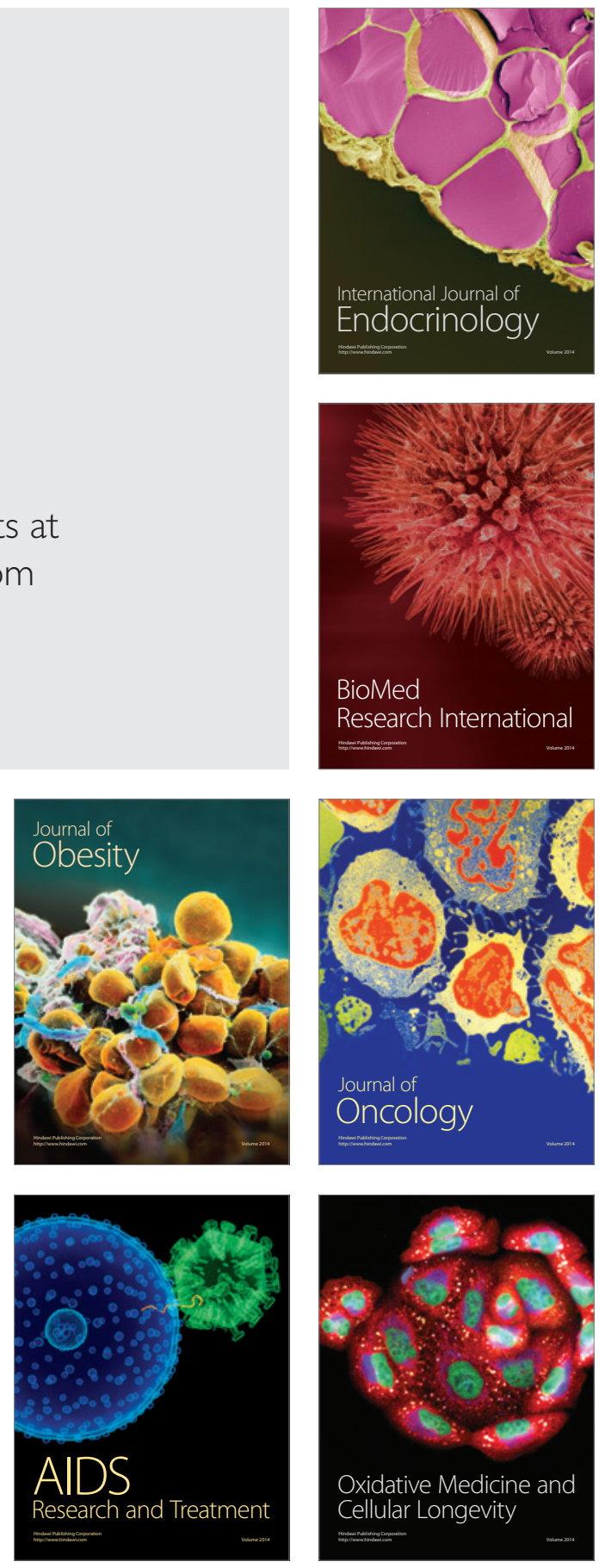